\title{
Factors that influence trace element levels in blood and feathers of Pygoscelis penguins from South Shetland Islands, Antarctica ${ }^{\text {is }}$
}

\author{
J.A. Padilha ${ }^{\text {a, }}{ }^{*}$, G.O. Carvalho ${ }^{\text {a }}$, W. Espejo ${ }^{\text {b }}$, J.S. Souza ${ }^{\text {e }}$, A.C. Pizzochero ${ }^{\text {a }}$, L.S.T. Cunha ${ }^{\text {a }}$, \\ E.S. Costa ${ }^{c}$, A.R.L. Pessôa ${ }^{\text {a }}$, A.P. Almeida ${ }^{\text {a }}$, J.P.M. Torres ${ }^{a}$, G. Lepoint ${ }^{\mathrm{d}}$, L.N. Michel ${ }^{\mathrm{d}, 1}$, \\ K. Das ${ }^{\mathrm{d}}$, P.R. Dorneles ${ }^{\mathrm{a}, \mathrm{d}}$ \\ ${ }^{a}$ Radioisotope Laboratory, Biophysics Institute, Federal University of Rio de Janeiro (UFRJ), Rio de Janeiro, Brazil \\ ${ }^{\mathrm{b}}$ Department of Animal Science, Facultad de Ciencias Veterinarias, Universidad de Concepción, P.0. Box 537, Chillán, Chile \\ ${ }^{\mathrm{c}}$ Mestrado Profissional Em Ambiente e Sustentabilidade, Universidade Estadual Do Rio Grande Do Sul, Rua Assis Brasil, 842, Centro, São Francisco de Paula, \\ Rio Grande do Sul, Brazil \\ ${ }^{\mathrm{d}}$ Freshwater and Oceanic Sciences Unit of Research (FOCUS), Laboratory of Oceanology, University of Liege, Belgium \\ e Department of Analytical Chemistry, Faculty of Chemistry, Adam Mickiewicz University, Ul. Uniwersytetu Poznańskiego 8, 61-614, Poznań, Poland
}

\section{A R T I C L E I N F O}

\section{Article history:}

Received 13 January 2021

Received in revised form 8 April 2021

Accepted 19 April 2021

Available online 23 April 2021

\section{Keywords:}

Marine pollution

Heavy metal

Antarctic seabird

Stable isotopes

\begin{abstract}
A B S T R A C T
Contaminant levels are lower in Antarctica than elsewhere in the world because of its low anthropogenic activities. However, the northern region of the Antarctic Peninsula, is close to South America and experiences the greatest anthropogenic pressure in Antarctica. Here, we investigated, in two Antarctic Peninsula islands, intra and interspecific factors that influence the concentrations of 17 trace elements (TEs) in blood and feathers of three penguin species breeding sympatrically in relation to their trophic ecology assessed via a stable isotopic approach $(C, N$ and $S)$. Geographical location, foraging zone $\left(\delta^{13} \mathrm{C}\right.$ and $\delta^{34} \mathrm{~S}$ ) and diet influences the interspecific difference, and sex and maturity stage diet influence the intraspecific difference of Pygoscelis penguins. Penguins from Livingston showed higher values (mean, ng. $\mathrm{g}^{-1}$, dry weight - dw) of $\mathrm{Zn}(103), \mathrm{Mn}(0.3)$, and Fe (95) than those from King George Island (Zn: 80, Mn: 1.9, and Fe: 11). Gender-related differences were observed, as males showed significantly higher values (mean, ng. $\mathrm{g}^{-1}$, dw) of $\mathrm{Rb}(3.4)$ and $\delta^{15} \mathrm{~N}$ in blood of gentoo, and Ca (1344) in Adélie feathers. Chicks of gentoo and Adélie presented higher $\mathrm{Zn}, \mathrm{Mg}, \mathrm{Ca}$, and $\mathrm{Sr}$ and lower ${ }^{13} \mathrm{C}$ values in blood than adults. The highest concentrations (mean, ng. $\mathrm{g}^{-1}, \mathrm{dw}$ ) of $\mathrm{Cd}(0.2)$ and $\mathrm{Cu}(26)$, and the lowest $\delta^{15} \mathrm{~N}$ values were found in chinstrap. Geographical, intraspecific (i.e., ontogenetic and gender-related) and interspecific differences in feeding seemed to have influenced TE and stable isotope values in these animals. The TE bioaccumulation by penguins may have also been influenced by natural enrichment in environmental levels of these elements, which seems to be the case for Fe, $\mathrm{Zn}$, and Mn. However, the high level of some of the TEs ( $\mathrm{Mn}, \mathrm{Cd}$, and $\mathrm{Cr}$ ) may reflect the increase of local and global human activities.
\end{abstract} (c) 2021 Elsevier Ltd. All rights reserved.

\section{Introduction}

The contamination of Antarctic environments largely reflects

\footnotetext{
This paper has been recommended for acceptance by Philip N. Smith.

* Corresponding author. Universidade Federal do Rio de Janeiro (UFRJ), Centro de Ciências da Saúde (CCS), Instituto de Biofísica Carlos Chagas Filho (IBCCF), Laboratório de Radioisótopos Eduardo Penna Franca (LREPF), Avenida Carlos Chagas Filho, 373, sala G0-62 Cidade Universitária, 21941-902, Rio de Janeiro, RJ, Brazil.

E-mail address: janeide.padilha@ufrj.br (J.A. Padilha).

1 Current address: Ifremer, Centre de Bretagne, REM/EEP, Laboratoire Environnement Profond, F-29280 Plouzané, France.
}

the use of chemicals in the southern half of the planet, a hemisphere with comparatively little land mass and smaller human population (Nash, 2011). This, combined with the shorter food chains of the Southern Ocean and the absence of subsisting human populations on the Antarctic continent, results in lower theoretical chemical risk for Antarctic biota (Abrams, 1985; Metcheva et al., 2010).

Despite the low environmental concentrations of pollutants in Antarctica these have been increasing over time, at global level, due to chemical pollution and to the global transport of persistent, bioaccumulative and toxic substances (PBTs) in the atmosphere and through oceanic circulation (Das et al., 2017; Jerez et al., 2011). In 
addition, at regional level, impacts due to the increase of research facilities and tourist activities, that occur mainly in the summer, has been detected in the region over the years (Bargagli, 2008; Jerez et al., 2011; Tin et al., 2009). From 1989 to 1990 (3146 tourists) to 2018-2019 (55,489 tourists) there was a considerable increase in tourism in Antarctica ("Data \& Statistics," 2021). This escalation in human presence over the years increases environmental concentrations of pollutants as trace elements (TEs), which are contaminants of concern due to their toxicity and bioaccumulative nature (Nordberg et al., 2014). In addition to tourism, few studies have investigated the contribution of the scientific stations operations and logistics for the accumulation of TEs (Hong et al., 2002; Kakareka et al., 2020; Tin et al., 2009). Naval operations (ballast water, fuel combustion), land-based activities (transport, maintenance of the research station), and the inefficient sewage management practices at several scientific stations contribute to local pollution of PBTs, that has the capacity to damage the local fauna and flora (Dobaradaran et al., 2018; Tin et al., 2009). Previous studies observed higher content of TEs in snow near human impacted areas when compared with the ice sheet (Kakareka et al., 2020) and higher TEs levels in feather samples of penguins from places with more anthropogenic influence (Jerez et al., 2011).

In addition to anthropogenic influence, the literature has shown a natural enrichment of TEs in Antarctic food webs through local volcanism, algal bloom, and upward flux of TE-rich waters. Antarctica is surrounded by the Antarctic Circumpolar Current, and the overturning circulation in the Southern Ocean replace superficial waters with deep waters from the surrounding oceans (Atlantic, Indian and Pacific), which can carry TEs with them (Bargagli et al., 1996; Bengtson Nash et al., 2010; Deheyn et al., 2005; Jiankan et al., 1999). However, the main source of pollutants for the Antarctic environment is global, not local (Bargagli, 2008).

Our study area, the northern region of the Antarctic Peninsula, is close to South America and experiences the greatest anthropogenic pressure in Antarctica. It is therefore vulnerable to the increase in contaminant concentrations (Espejo et al., 2017; Tin et al., 2009). TEs levels in sediments from South Shetland Islands and the northern zone of the Antarctic Peninsula has increased, and this seems to result from a growth in local and global anthropogenic activities (Celis, 2012, 2015; Espejo et al., 2017). King George Island, located in Antarctic Peninsula, presents a great concentration of anthropogenic activities, where most Antarctic scientific stations in the region are located, being one of the favorite destinations for tourists as well (Jerez et al., 2011; Tin et al., 2009).

Penguins are valuable sentinels of environmental pollution, due to their abundance and longevity, which is approximately 20 years (Bargagli, 2008; Burger and Gochfeld, 2000; Herman et al., 2017; Jerez et al., 2011; Metcheva et al., 2006). Antarctic penguins provide an important contribution to total avian biomass in the Southern Ocean (Bargagli, 2008; Metcheva et al., 2006). Pygoscelis penguins have a circumpolar distribution, and as a result, their tissues are matrices of choice for contaminant biomonitoring in Antarctica (Jerez et al., 2013a; 2011; Metcheva et al., 2006). Generally, chinstrap (Pygoscelis antarcticus) and Adélie (Pygoscelis adeliae) penguins forage primarily on Antarctic krill further offshore in pelagic areas (Trivelpiece et al., 1987). Gentoo penguins (Pygoscelis papua) forage on a mix of krill and fish, in deeper benthic habitats (Herman et al., 2017; Miller et al., 2010), but the literature reported geographical variations in the diet among $P$. papua due to dissimilarities in prey availability at different breeding locations (Deheyn et al., 2005). Differences in foraging habitat use, prey preferences, larger-scale migration, and dispersal strategies can expose seabirds breeding in the same location to different TEs concentrations
(Carravieri et al., 2014; Polito et al., 2015).

Little is known about polar seabirds contamination by TEs, which is highly variable among taxa; thus, there is a need for further studies to better understand the accumulation patterns of TEs in seabirds' bodies (Espejo et al., 2017; Jerez et al., 2013a; Metcheva et al., 2010). Previous studies have basically focused on TEs in feathers of adults and on interspecific differences between Pygoscelis penguins (Jerez et al., 2011; Metcheva et al., 2006). Although diet represents the main source of TEs for consumers, factors other than trophic position, ontogenetic and sex-related differences, foraging habitat, or movements have been suggested to drive accumulation patterns in wildlife and still poorly understood (Colominas-Ciuró et al., 2018; Herman et al., 2017). Therefore, a better understanding of the presence of TEs in polar seabirds can help in an assessment of the sources and fate of these pollutants in remote regions and shed new light on the global transport and distribution of TEs.

To fill this gap, we measured the concentrations of 17 TEs and the stable isotopes compositions $(\mathrm{C}, \mathrm{N}, \mathrm{S})$ in blood and feather of Pygoscelis penguins ( $P$. adeliae, P. antarcticus, $P$. papua) breeding in sympatry in the South Shetland Islands to investigate individual and populational differences in trace element concentrations, and to assess how their trophic ecology can influence their exposure to TEs. In addition, we explored small scale geographical differences between King George and Livingston Islands, in order to better understand how natural sources and/or anthropogenic pressures can influence TEs values.

\section{Material and methods}

\subsection{Sampling}

Feather and blood sampling were performed at King George $\left(61^{\circ} 50^{\prime} \mathrm{S}-57^{\circ} 30^{\prime} \mathrm{W}\right)$ and Livingston $\left(62^{\circ} 39^{\prime} \mathrm{S}-60^{\circ} 35^{\prime} \mathrm{W}\right)$ Islands in the South Shetland Archipelago, Antarctic Peninsula region, during the 2012-2013 and 2013-2014 austral summers (Fig. 1). Adult and juvenile penguins were captured during the breeding season with long-handled fish nets. Each captured animal was banded with an aluminum ring, weighed, and measured (beak size, wing, tail) with digital caliper or ruler and freed after measurements and sampling. Breast feather samples of all species were cut close to their base with stainless steel scissors. Blood samples $(1 \mathrm{~mL})$ were taken from each individual using disposable syringe and needle, stored into identified Eppendorfs, and kept frozen at $-80{ }^{\circ} \mathrm{C}$ until being freeze-dried prior to TEs measurements. The number of samples per location, species, gender, state of maturity, and tissue are presented in Table 1.

\subsection{Sample preparation}

Breast feather samples were washed three times with a sequence of Milli-Q ultrapure water (Merck Millipore, USA), $0.01 \%$ EDTA (Spectrum, Tedia, USA) and finally Milli-Q ultrapure water (Merck Millipore, USA) again, for eliminating external contamination, and oven-dried at $50{ }^{\circ} \mathrm{C}$ for $24 \mathrm{~h}$ (Marques, 2007) before being grounded into a fine powder using stainless steel scissors. For trace element measurements, aliquots of approximately $0.1 \mathrm{~g}$ of dry powdered feathers and freeze-dried blood samples were subjected to acid digestion in the microwave, in Teflon vessels, with the addition of $5 \mathrm{~mL}$ of nitric acid $\left(\mathrm{HNO}_{3}, 65 \%\right.$ suprapur Merck, Germany), $2 \mathrm{~mL}$ of hydrogen peroxide $\left(\mathrm{H}_{2} \mathrm{O}_{2}, 30 \%\right.$ suprapur Merck, Germany) and $1 \mathrm{~mL}$ of Milli-Q ultrapure water (Merck Millipore, USA). For stable isotopes measurements, feather samples were additionally washed with a chloroform/methanol (2:1, v:v, 


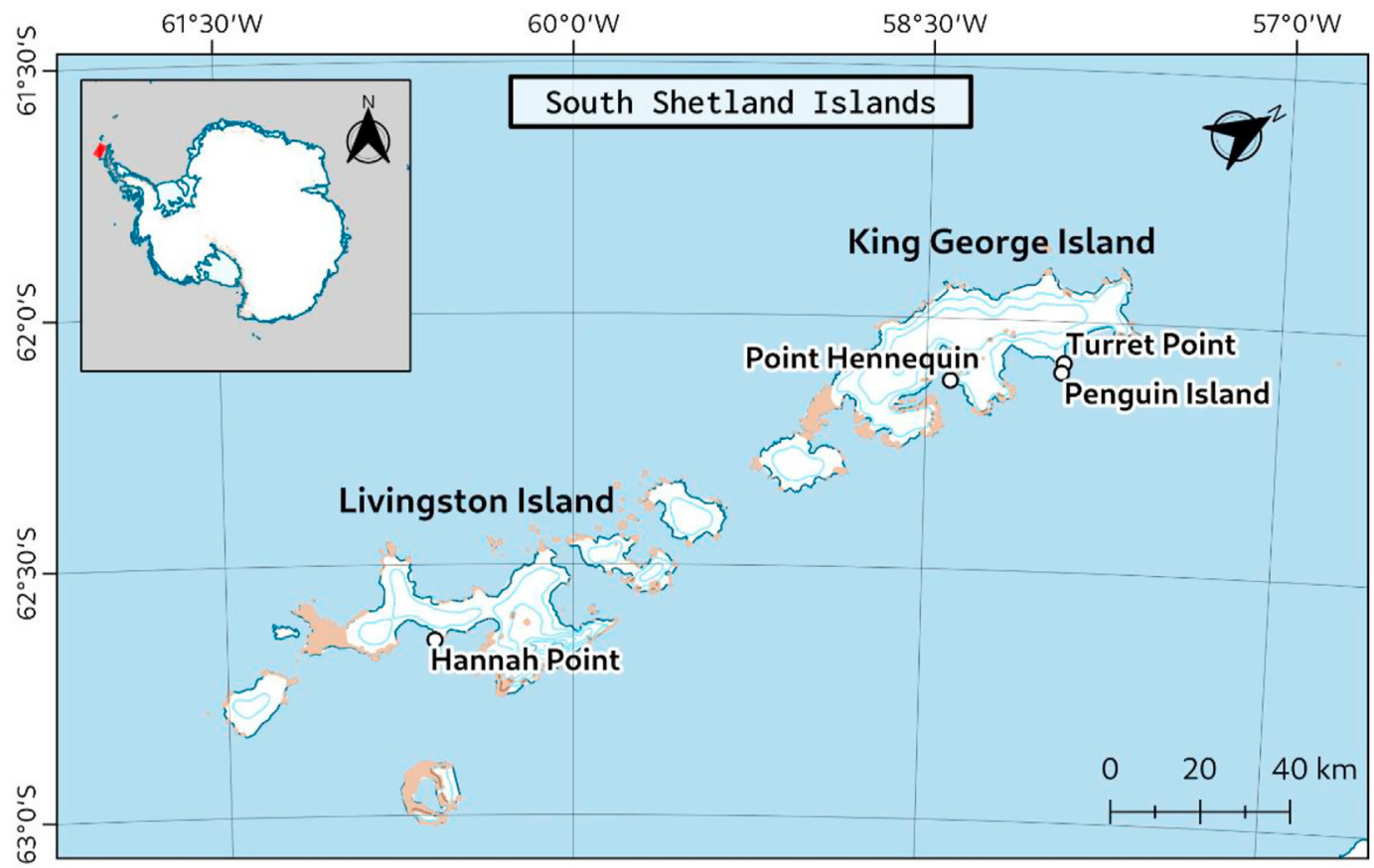

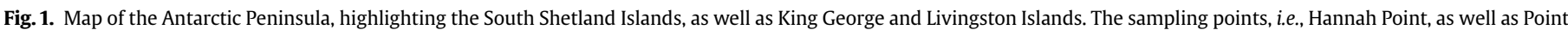
Hennequin, Penguin Island, and Turret Point are additionally stressed.

Table 1

Sampling data (tissue, species, state of maturity, and number of individuals $-n$ ) from King George Island (Point Hennequin, Penguin Island and Turret Point) and Livingston Island (Hannah Point) in the Antarctic Peninsula during 2012-2013 and 2013-2014 austral summers.

\begin{tabular}{lllll}
\hline Tissue & Species & State of maturity & $n$ & Location \\
\hline Blood & Pygoscelis antarcticus & Adult & 35 & King George \\
& & & 5 & Livingston \\
& Pygoscelis adeliae & Adult & 17 & King George \\
& & Chicks & 9 & King George \\
& Pygoscelis papua & Adult & 31 & King George \\
& & & 17 & Livingston \\
Feathers & Chicks & 8 & Livingston \\
& & Adult & 21 & King George \\
& Pygoscelis adeliae & Adult & 4 & Livingston \\
& Pygoscelis papua & Adult & 17 & King George \\
& & & 22 & King George \\
& & & 6 & Livingston \\
\hline
\end{tabular}

suprapur Merck, Germany) solution, and drid at $50{ }^{\circ} \mathrm{C}$ for $48 \mathrm{~h}$.

\subsection{ICP-MS analysis}

Lithium (Li), Be, Mg, Ca, Cr, Fe, Mn, Ni, Cu, Zn, Se, Rb, Sr, Cd, Sn, Ba and $\mathrm{Pb}$ concentrations were determined by inductively coupled plasma - mass spectrometry (ICP-MS), using a PerkinElmer Elan 9000 spectrometer following the methodology described in Lehnert et al. (2016). Blanks were carried through the procedure in the same way as the samples, as it was the case for the reference materials NIES-1 (human hair) and SERONORM L-3 (whole blood). Reference material results were in good agreement (recovery between 90 and 110\%) with the values certified by the National Institute for Environmental Studies (NIES). The detection limits of the method, in $\mu$ g. $\mathrm{g}^{-1}$, were: 0.046 for $\mathrm{Li} ; 0.049$ for Be; 0.38 for $\mathrm{Mg}$; 1.247 for $\mathrm{Ca}$; 0.007 for $\mathrm{Cr}$; 0.917 for $\mathrm{Fe} ; 0.01$ for $\mathrm{Mn}$; 0.27 for $\mathrm{Ni}$; 1.063 for $\mathrm{Cu} ; 0.12$ for $\mathrm{Zn}$; 0.034 for Se; 0.005 for $\mathrm{Rb} ; 0.005$ for $\mathrm{Sr}$; 0.006 for Cd; 0.047 for Sn; 0.004 for Ba; and 1.329 for Pb.

\subsubsection{Stable isotope measurements}

Stable isotopes measurements were performed via continuous flow - elemental analysis - isotope ratio mass spectrometry (CF-EAIRMS) using a Vario MICRO cube $\mathrm{C}-\mathrm{N}-\mathrm{S}$ elemental analyzer (Elementar Analysensysteme GmBH, Hanau, Germany) coupled to an IsoPrime100 isotope ratio mass spectrometer (Isoprime, Cheadle, United Kingdom). Isotopic ratios were conventionally expressed as $\delta$ values in \%o (Coplen, 2011) and relative to the international standards: Vienna Pee Dee Belemnite, for carbon; Atmospheric Air, for nitrogen; and Vienna Canyon Diablo Troilite, for sulphur. We used International Atomic Energy Agency (IAEA, Vienna, Austria) certified reference materials IAEA-C6 $\left(\delta^{13} \mathrm{C}=-10.8 \pm 0.5 \%\right.$; mean \pm SD), IAEA-N2, $\left(\delta^{15} \mathrm{~N}=20.3 \pm 0.2 \%\right.$; mean \pm SD $)$ and IAEAS1 $\left(\delta^{34} \mathrm{~S}=-0.3 \%\right.$; mean $)$ as primary analytical standards, and sulfanilic acid $\left(\delta^{13} \mathrm{C}=-25.9 \pm 0.3 ; \quad \delta^{15} \mathrm{~N}=-0.12 \pm 0.4\right.$; $\delta^{34} \mathrm{~S}=5.9 \pm 0.6$; mean \pm SD in each case) as secondary analytical standards. Isotopic ratios of samples were calibrated using primary analytical standards. Standard deviations on multi-batch replicate measurements of secondary analytical (sulfanilic acid) and lab standards (blood and feathers) analyzed interspersed among samples (one replicate of each standard every 15 analyses) were $0.2 \%$ for both $\delta^{13} \mathrm{C}$ and $\delta^{15} \mathrm{~N}$ and $0.4 \%$ for $\delta^{34} \mathrm{~S}$.

\subsection{Molecular determination of sex}

Molecular analyzes of sex were performed at the Laboratory of Marine Genetics, at the Department of Genetics, at the State University of Rio de Janeiro (UERJ) using the molecular technique of the CHD gene developed by Griffiths et al. (1998). Not all adult samples could be determined by gender, so those that could are listed in Tables 2 and 3 .

\subsection{Statistical analysis}

For statistics, non-parametric (Mann-Whitney $U$ test, Spearman correlation test-r and Kruskal-Wallis) tests were used. We analyzed 
Table 2

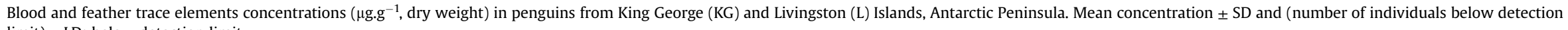
limit). <LD: below detection limit.

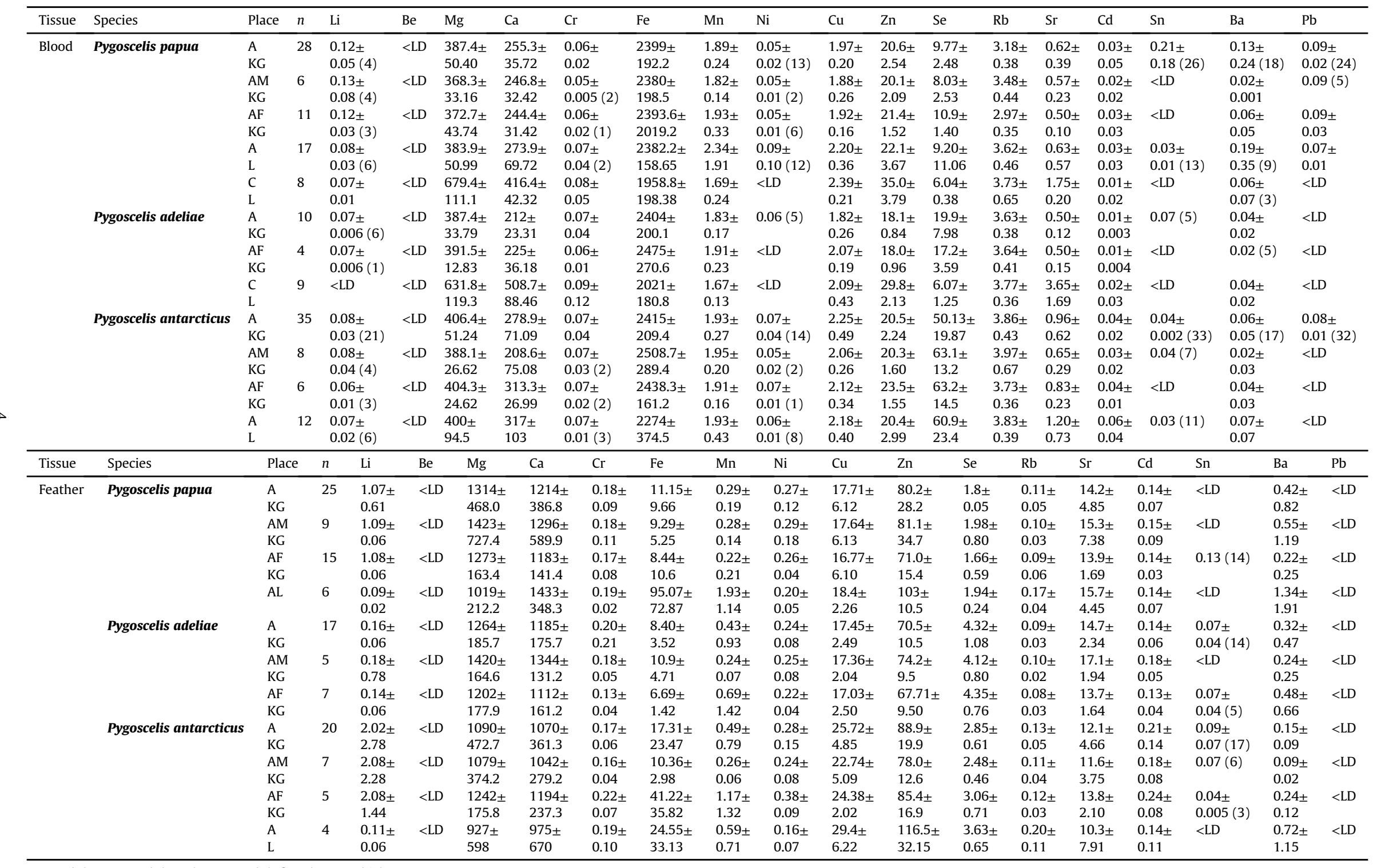

*A = adult; $\mathrm{AM}=$ adult male; $\mathrm{AF}=$ adult female; $\mathrm{C}=$ chick. 
Table 3

The values of $\delta^{13} \mathrm{C}, \delta^{15} \mathrm{~N}$ and $\delta^{34} \mathrm{~S}$ in blood and feathers of gentoo, Adélie and chinstrap penguins from King George and Livingston Islands.

\begin{tabular}{|c|c|c|c|c|c|c|c|}
\hline Tissue & Specie & Place & Age & $n$ & $\delta^{13} \mathrm{C}(\% 0)$ & $\delta^{15} \mathrm{~N}(\% 0)$ & $\delta^{34} \mathrm{~S}(\% 0)$ \\
\hline \multirow[t]{12}{*}{ Blood } & Pygoscelis papua & King George & Adult & 29 & $\begin{array}{l}-26.47 \\
\pm 0.46\end{array}$ & $\begin{array}{l}7.88 \\
\pm 0.35\end{array}$ & - \\
\hline & & & Male & 10 & $\begin{array}{l}-26.40 \\
\pm 0.34\end{array}$ & $\begin{array}{l}7.99 \\
\pm 0.29\end{array}$ & - \\
\hline & & & Female & 16 & $\begin{array}{l}-26.50 \\
\pm 0.47\end{array}$ & $\begin{array}{l}7.77 \\
\pm 0.39\end{array}$ & - \\
\hline & & Livingston & Adult & 19 & $\begin{array}{l}-26.06 \\
\pm 0.21\end{array}$ & $\begin{array}{l}8.38 \\
\pm 0.33\end{array}$ & - \\
\hline & & & Chicks & 7 & $\begin{array}{l}-27.61 \\
\pm 0.16\end{array}$ & $\begin{array}{l}7.96 \\
\pm 0.26\end{array}$ & - \\
\hline & Pygoscelis adeliae & King George & Adult & 5 & $\begin{array}{l}-26.13 \\
\pm 0.28\end{array}$ & $\begin{array}{l}8.09 \\
\pm 0.29\end{array}$ & - \\
\hline & & & Female & 3 & $\begin{array}{l}-26.36 \\
\pm 0.25\end{array}$ & $\begin{array}{l}7.95 \\
\pm 0.29\end{array}$ & - \\
\hline & & & Chicks & 9 & $\begin{array}{l}-27.37 \\
\pm 1.51\end{array}$ & $\begin{array}{l}8.08 \\
\pm 1.01\end{array}$ & - \\
\hline & Pygoscelis antarcticus & King George & Adult & 16 & $\begin{array}{l}-26.15 \\
\pm 0.62\end{array}$ & $\begin{array}{l}8.21 \\
\pm 0.31\end{array}$ & - \\
\hline & & & Male & 8 & $\begin{array}{l}-25.94 \\
\pm 0.62\end{array}$ & $\begin{array}{l}8.17 \\
\pm 0.24\end{array}$ & - \\
\hline & & & Female & 6 & $\begin{array}{l}-26.28 \\
\pm 0.45\end{array}$ & $\begin{array}{l}8.02 \\
\pm 0.29\end{array}$ & - \\
\hline & & Livingston & Adult & 4 & $\begin{array}{l}-26.62 \\
\pm 0.61\end{array}$ & $\begin{array}{l}8.47 \pm \\
0.53\end{array}$ & - \\
\hline \multirow[t]{10}{*}{ Feather } & Pygoscelis papua & King George & Adult & 26 & $\begin{array}{l}-24.76 \\
\pm 0.69\end{array}$ & $\begin{array}{l}9.61 \\
\pm 0.46\end{array}$ & $\begin{array}{l}15.28 \\
\pm 0.97\end{array}$ \\
\hline & & & Male & 8 & $\begin{array}{l}-24.36 \\
\pm 0.50\end{array}$ & $\begin{array}{l}9.89 \\
\pm 0.47\end{array}$ & $\begin{array}{l}15.56 \\
\pm 0.65\end{array}$ \\
\hline & & & Female & 14 & $\begin{array}{l}-25.04 \\
\pm 0.73\end{array}$ & $\begin{array}{l}9.54 \\
\pm 0.28\end{array}$ & $\begin{array}{l}15.39 \\
\pm 1.04\end{array}$ \\
\hline & & Livingston & Adult & 6 & $\begin{array}{l}-24.89 \\
\pm 0.78\end{array}$ & $\begin{array}{l}9.67 \\
\pm 0.69\end{array}$ & $\begin{array}{l}13.33 \\
\pm 1.11\end{array}$ \\
\hline & Pygoscelis adeliae & King George & Adult & 20 & $\begin{array}{l}-24.48 \\
\pm 0.80\end{array}$ & $\begin{array}{l}9.72 \\
\pm 0.47\end{array}$ & $\begin{array}{l}14.91 \\
\pm 1.07\end{array}$ \\
\hline & & & Male & 6 & $\begin{array}{l}-24.64 \\
\pm 1.03\end{array}$ & $\begin{array}{l}9.98 \\
\pm 0.46\end{array}$ & $\begin{array}{l}14.70 \\
\pm 1.18\end{array}$ \\
\hline & & & Female & 7 & $\begin{array}{l}-24.45 \\
\pm 0.63\end{array}$ & $\begin{array}{l}9.70 \\
\pm 0.39\end{array}$ & $\begin{array}{l}15.32 \\
\pm 1.07\end{array}$ \\
\hline & Pygoscelis antarcticus & King George & Adult & 20 & $\begin{array}{l}-25.39 \\
\pm 0.74\end{array}$ & $\begin{array}{l}9.25 \\
\pm 0.50\end{array}$ & $\begin{array}{l}14.39 \\
\pm 1.07\end{array}$ \\
\hline & & & Male & 5 & $\begin{array}{l}-25.51 \\
\pm 0.90\end{array}$ & $\begin{array}{l}9.13 \\
\pm 0.71\end{array}$ & $\begin{array}{l}14.03 \\
\pm 1.03\end{array}$ \\
\hline & & & Female & 6 & $\begin{array}{l}-25.33 \\
\pm 0.91\end{array}$ & $\begin{array}{l}8.93 \\
\pm 0.67\end{array}$ & $\begin{array}{l}14.99 \\
\pm 1.42\end{array}$ \\
\hline
\end{tabular}

the relationship between trace element concentrations and stable isotopes among three species of penguins using a principal component analysis (PCA). Linear regression analyses were used to assess the relationship between TEs concentrations and stable isotopes $\left(\delta^{15} \mathrm{~N}, \delta^{13} \mathrm{C}, \delta^{34} \mathrm{~S}\right)$ values. Statistical analyses were performed in R (R Core Team, 2019) statistical software and Statistica 7.

Individuals were grouped by species (P. adeliae, $P$. antarcticus, P. papua), life stage (adult and chick), location (King George and Livingston islands) and sample type (blood and feathers). Ecological niches across different species were explored using the SIBER (Stable Isotope Bayesian Ellipses in R) method (Jackson, 2011). The ellipse areas were estimated using the SEA $A_{C}$ correction, as well as the Bayesian modelling ( $S E A_{b}, 106$ iterations) for intergroup pairwise comparisons (Jackson et al., 2011). The SEA mate of the standard ellipse area) can be used to compare niche widths between groups, based on the size of simulated ellipse areas and their estimated posterior distributions. Groups with similar $\mathrm{SEA}_{\mathrm{b}}$ have similar isotopic niche width, i.e., rely on a similar diversity of prey items and/or feeding habitats. For this purpose, the SIBER 2.1.4 method (Jackson et al., 2011) was run in R (R Core Team, 2019) statistical environment.

\section{Results}

Essential (Mg, Ca, Fe, Mn, Cu, Zn, Se) and nonessential (Li, Be, Cr, $\mathrm{Rb}, \mathrm{Sr}, \mathrm{Cd}, \mathrm{Sn}, \mathrm{Ba}$ and $\mathrm{Pb}$ ) trace element concentrations in blood and feathers of gentoo (P. papua), chinstrap ( $P$. antarcticus) and Adélie (P. adeliae) penguins from King George and Livingston islands are given in Table 2.

No significant correlation was found between blood and feather TE concentrations except for a negative correlation for $\mathrm{Rb}$ $\left(\mathrm{r}^{2}=0.65 ; p=0.003\right)$ in $P$. antarcticus, as well as for a positive correlation for $\mathrm{Cu}$ in $P$. papua $\left(\mathrm{r}^{2}=0.49 ; p=0.039\right)$.

The $\delta^{13} \mathrm{C}, \delta^{15} \mathrm{~N}$ and $\delta^{34} \mathrm{~S}$ values for blood and feathers of $P$. papua, $P$. adeliae and $P$. antarcticus from King George and Livingston islands are shown on Table 3. There was no significant correlation between feather and blood isotope values in any of the three penguin species.

\subsection{Geographical differences}

Significant differences in trace element concentrations in blood and feathers between sampling locations were observed only for P. papua adults (Figure S1 of the Supplementary Material). Blood samples from King George Island presented lower $\mathrm{Rb}$ 
concentrations $(p<0.01)$ than those from Livingston. Feather samples from Livingston Island presented higher $\mathrm{Zn}, \mathrm{Mn}$, Fe and Rb concentrations $(p<0.01)$ than those from King George Island.

\subsection{Intraspecific differences}

Gender-related differences: Feather and blood concentrations of several TEs were significantly different between males and females $(p>0.001)$, and these sex-related differences were found in distinct patterns for the three studied species (Figure S2 of the Supplementary Material). In P. papua, significantly higher blood Rb concentrations were found in males than in females, while in $P$. antarcticus, blood $\mathrm{Ca}$ and $\mathrm{Zn}$ concentrations were significantly higher in females than in males. In P. adeliae, significantly higher $\mathrm{Ca}$ values in feathers were found in males than in females. In $P$. antarcticus, $\mathrm{Sr}$ values in feathers were significantly higher in females than in males.

Regarding sexual differences in stable isotope ratios, males of P. papua showed significantly higher $\delta^{15} \mathrm{~N}$ values than females for both, blood $\left(\mathrm{U}_{-2.47}=33 ; p=0.013\right)$ values. On the other hand, females presented higher $\delta^{13} \mathrm{C}\left(\mathrm{U}_{-2.32}=22 ; p=0.020\right)$ values in feathers than males.

Ontogenetic differences: Significant differences in blood concentrations of several TEs were observed between adults and chicks, and such dissimilarities were verified for $P$. papua and P. adeliae (Fig. 2). It was not possible to perform this comparison for $P$. antarcticus, as only adults of this species were sampled. Concerning P. papua, chicks showed significantly higher $\mathrm{Zn}, \mathrm{Mg}$, Ca, and
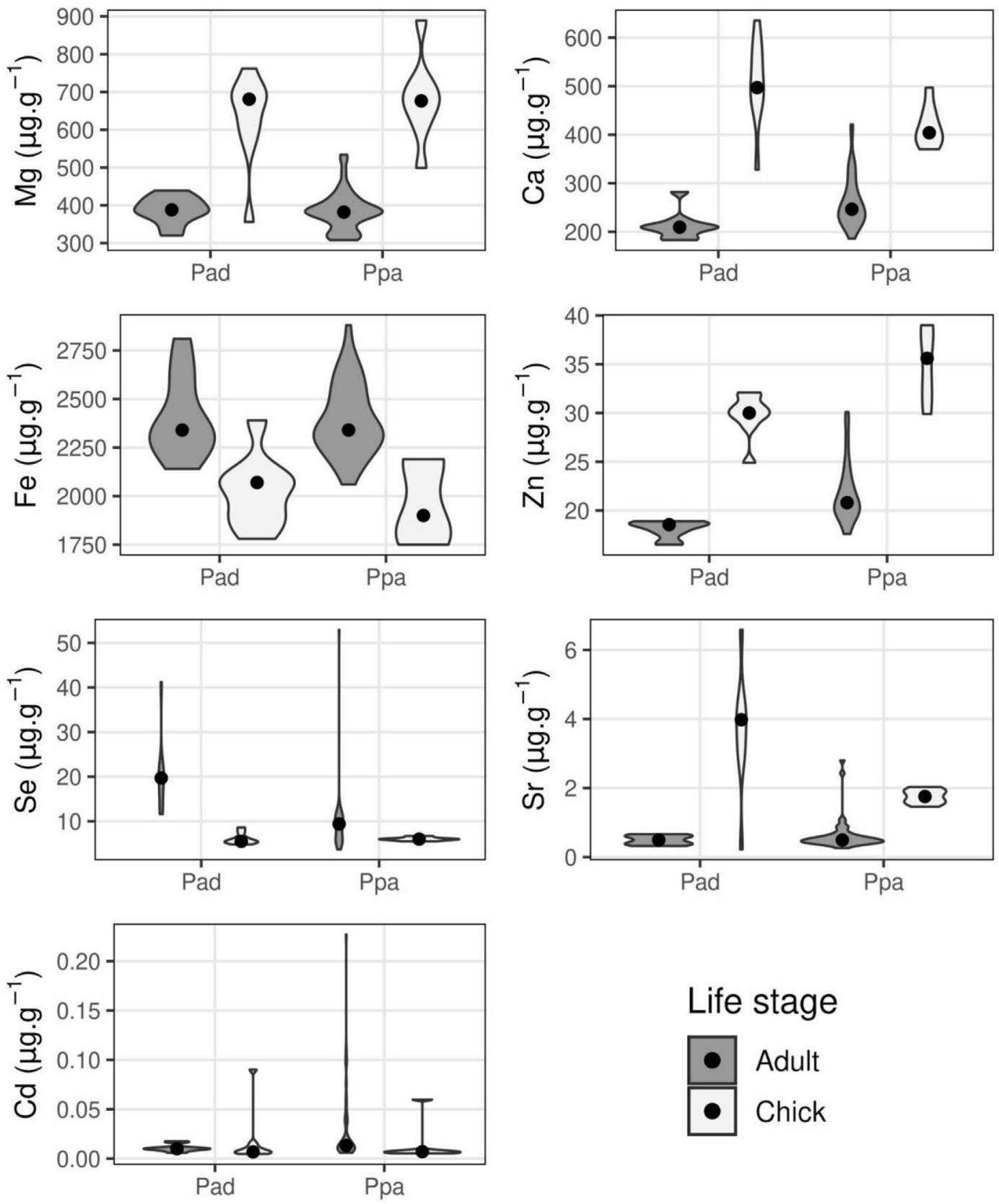

\section{Life stage}

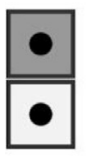

Adult

Chick

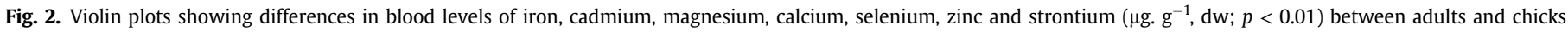
regarding Pygoscelis papua - Ppa from Livingston Island, and Pygoscelis adeliae - Pad from King George Island, Antarctic Peninsula. 
Sr concentrations than adults, while concentrations of Fe, Se and Cd were significantly higher in adults than in chicks. A similar pattern was observed for P. adeliae (Fig. 2), i.e., chicks showed significantly higher $\mathrm{Zn}, \mathrm{Mg}, \mathrm{Ca}$, and $\mathrm{Sr}$ concentrations than adults. Still concerning $P$. adeliae, blood Fe and Se concentrations were significantly higher in adults than in chicks. Using weight for investigating the possible occurrence of TE bioaccumulation, significant negative correlations were observed between the weight $(\mathrm{g})$ and two elements, $\mathrm{Se}(\mathrm{R}=-0.65, p<0.001)$ and $\mathrm{Cu}(\mathrm{R}=-0.32, p=0.008)$. In addition, a significant positive correlation was found between the weight $(\mathrm{g})$ and Ca levels $(\mathrm{R}=0.30, p=0.01)$.

For stable isotope, chicks of $P$. adeliae and $P$. papua presented ${ }^{13} \mathrm{C}$-depleted blood values in comparison to adults $\left(\mathrm{H}_{75.11}=43.94\right.$; $p<0.005$ and $\mathrm{H}_{80.62}=43.94 ; p<0.001$, respectively).

\subsection{Interspecific differences}

Regarding blood concentrations (Fig. 3A), principal component 1 (PC1, 31.6\%) had negative loadings of $\mathrm{Mg}(-0.45), \mathrm{Zn}(-0.44), \mathrm{Ca}$ $(-0.45)$ and had positive loadings of Fe $(0.30)$, with the weakest contribution from Cd (0.06). PC1 tended to separate chicks from adults (Fig. 3A). PC2 explained $16.2 \%$ of the overall variation, with the strongest positive contributions from $\mathrm{Mn}(0.43)$ and $\mathrm{Rb}(0.43)$ and the weakest one from $\mathrm{Ca}(0.05)$. Regarding feather values (Fig. 3B), principal component 1 (PC1, 29\%) had positive contributions from $\mathrm{Ca}(0.41), \mathrm{Sr}(0.38)$ and $\mathrm{Mg}(0.34)$ and the weakest one from Cs $(-0.03)$. PC2 explained $16.4 \%$ of the overall variation, with the strongest positive contributions from $\mathrm{Rb}(0.39)$ and $\mathrm{Zn}(0.38)$ and the weakest one from $\mathrm{Mg}(-0.43)$. Nevertheless, there was a clear overlap among the multivariate TE profiles in adults of the

A)

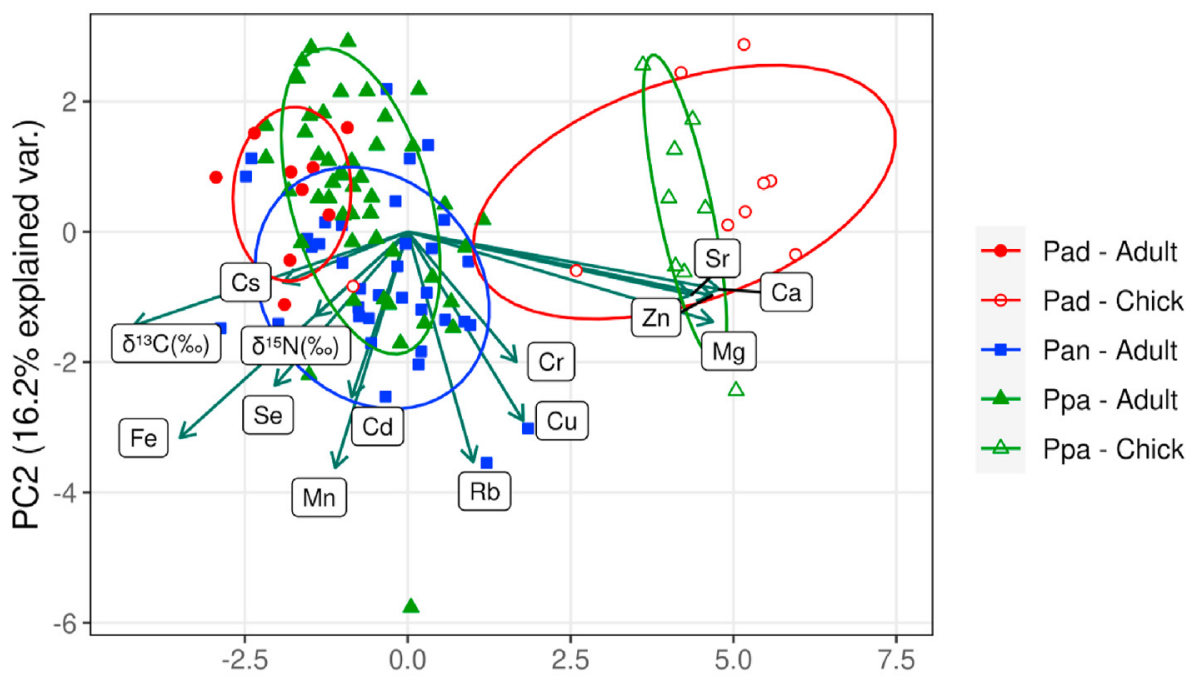

B)

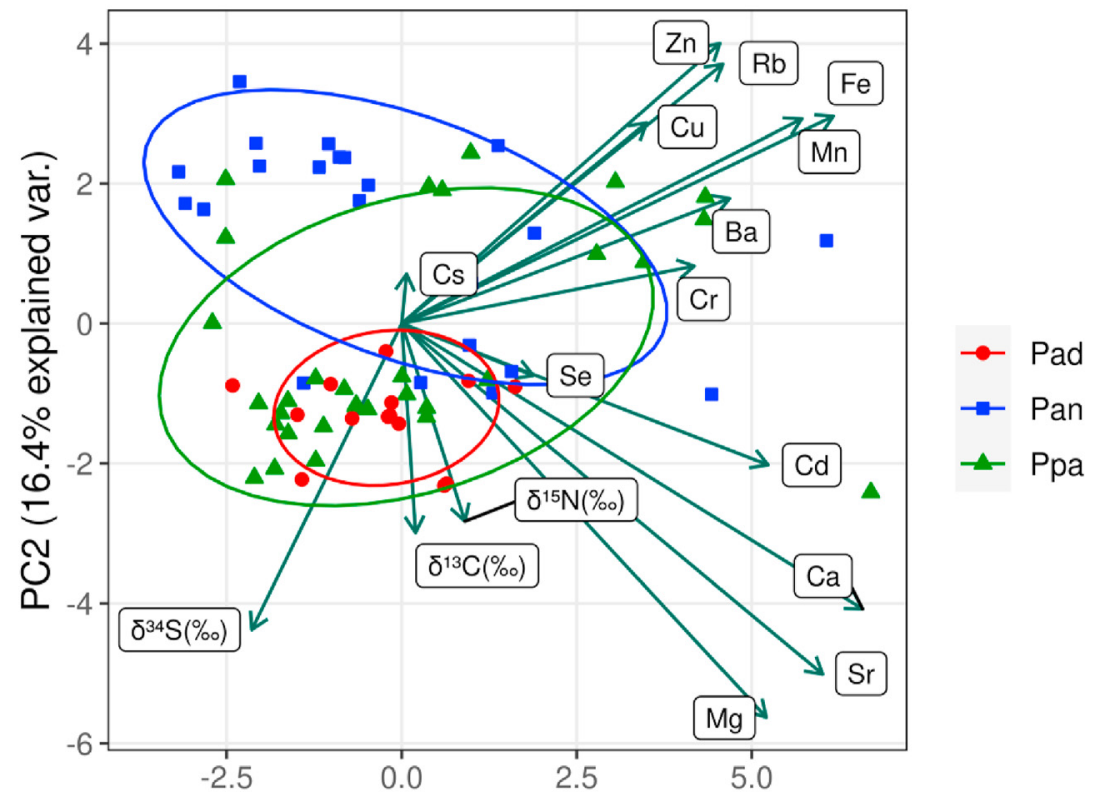

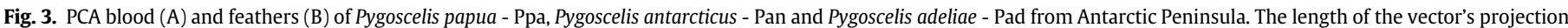

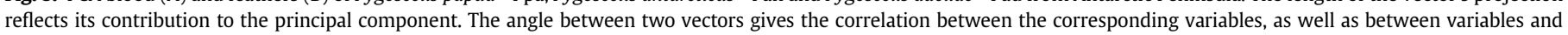
principal components. Acute or obtuse angles indicate positive or negative correlations, respectively. A right angle indicates no correlation. 
three studied species.

The highest blood Li concentrations $(H=20.81, p<0.001)$ were found in $P$. adeliae. The highest blood values of $\mathrm{Mn}(\mathrm{H}=8.74$, $p=0.03)$, Se $(\mathrm{H}=82.46, p<0.001)$, and $\mathrm{Cd}(\mathrm{H}=37.16, p<0.001)$ were found in $P$. antarcticus. The highest feather concentrations of $\mathrm{Cu}(\mathrm{H}=31.12, p<0.001), \mathrm{Zn}(\mathrm{H}=13.31, \mathrm{p}<0.05)$ and $\mathrm{Rb}(\mathrm{H}=14.45$, $p<0.05)$ were found in $P$. antarcticus; as well as the highest Se concentrations were found in P. adeliae $(\mathrm{H}=37.52, p<0.001)$. In addition, $\mathrm{Se}(\mathrm{H}=41.55, p<0.001)$ concentrations were significantly higher in feather of $P$. antarcticus than in $P$. papua, as it was the case for $\mathrm{Sr}$ as well $(\mathrm{H}=7.28, p<0.05)$.

\subsection{Stable isotope ratios and trace element patterns}

Regarding feather samples from King George, $P$. antarcticus showed significantly lower values of both $\delta^{15} \mathrm{~N}$ and $\delta^{13} \mathrm{C}$ than P. adeliae $\left(\mathrm{U}_{2.50}=81, p=0.012\right.$ for $\delta^{15} \mathrm{~N} ; \mathrm{H}_{39.76}=13.55, p=0.019$ for $\left.\delta^{13} \mathrm{C}\right)$ and $P$. papua $\left(\mathrm{U}_{-2.26}=178, p=0.024\right.$ for $\delta^{15} \mathrm{~N} ; \mathrm{H}_{44.13}=13.55$; $p=0.007$ for $\left.\delta^{13} \mathrm{C}\right)$. Regarding $\delta^{34} \mathrm{~S}, P$. papua from King George Island showed significantly higher values than $P$. antarcticus $\left(\mathrm{H}_{28.96}=13.86 ; p=0.043\right)$ and $P$. papua $\left(\mathrm{H}_{14.83}=13.86 ; p=0.007\right)$ from Livingston Island.

Correlation analyses between stable isotope ratios and TEs concentrations in blood and feathers of P. papua, $P$. adeliae and $P$. antarcticus are presented on Fig. 4. Significant negative correlations were found between $\delta^{15} \mathrm{~N}$ and four elements $(\mathrm{Cr}, \mathrm{Zn}, \mathrm{Cd}$, and $\mathrm{Rb}$ ) for blood, as well as $\delta^{15} \mathrm{~N}$ and six elements (Mg, Ca, Cr, Sr, Cd, and $\mathrm{Fe}$ ) for feather. Positive correlations were found in feathers between $\delta^{15} \mathrm{~N}$ and five elements (Se, Mg, Ca, Se and Sr). Significant negative correlations were found between $\delta^{13} \mathrm{C}$ and six metals $(\mathrm{Mg}$, $\mathrm{Ca}, \mathrm{Cr}, \mathrm{Zn}, \mathrm{Cu}$ and $\mathrm{Sr}$ ) for blood, as well as between $\delta^{13} \mathrm{C}$ and three elements ( $\mathrm{Zn}, \mathrm{Cd}$ and $\mathrm{Se}$ ) for feathers. Significant positive correlations were found between $\delta^{13} \mathrm{C}$ and five elements (Fe, Mn, Se, Cd and $\mathrm{Cs}$ ) in blood samples. Significant negative correlations were found between $\delta^{34} \mathrm{~S}$ and six elements $(\mathrm{Cr}, \mathrm{Fe}, \mathrm{Mn}, \mathrm{Zn}, \mathrm{Rb}$ and $\mathrm{Ba})$ for feathers.

\subsection{Stable isotope ellipses}

SIBER results (Fig. 5) suggest that the core isotopic niches of the chicks of $P$. papua and $P$. adeliae were markedly separated from the groups of adults. Regarding feathers from adults, the overlap between the $P$. adeliae and P. papua from King George Island was $0.84 \%{ }^{2}$ (i.e., $53 \%$ of its area). The overlap between P. papua in feathers of adults from King George and Livingston islands was considerable for carbon and nitrogen $\left(0.86 \% 0^{2}\right.$, i.e., $64 \%$ of its cumulative area). Concerning blood, a moderate overlap was observed in $P$. antarcticus from King George and Livingston islands $\left(0.35 \%{ }^{2}\right.$, i.e., $22 \%$ of its area), and a weak overlap was found in P. papua from King George and Livingston islands $\left(0.05 \% 0^{2}\right.$, i.e., $7 \%$ of its area).

Areas of the standard ellipses associated with each penguin group varied in a narrow range for feathers and a moderate one for blood, with SEAc values ranging from $1.09 \% 0^{2}$ to $1.33 \% 0^{2}$ for feathers and from $0.28 \% 0^{2}-2.21 \% 0^{2}$ for blood (Fig. 6). P. papua and P. adeliae from King George Island showed smaller isotopic niches than P. antarcticus for blood $(99.8 \%$ and $97.4 \%$ of model solutions, respectively) and $P$. adeliae chicks showed the largest isotopic niche (>99\% of model solutions).

The three penguin species had similar isotopic niche sizes in King George Island for feathers. P. papua from Livingston and King George islands differed in only $36.6 \%$ of model solutions.

\section{Discussion}

To the best of our knowledge, this research analyzed for the first time multivariables in order to understand which factors may influence the exposure of Pygoscelis penguins to TEs through the analysis of feather and blood. These matrices did not show significant correlations in TEs and stable isotope values. Significant differences for TEs and stable isotopes values were found among species within the studied breeding localities. TEs interspecific differences are related to diet, foraging zone $\left(\delta^{13} \mathrm{C}\right.$ and $\left.\delta^{34} \mathrm{~S}\right)$ and geographical location, but poorly by the trophic position $\left(\delta^{15} \mathrm{~N}\right)$. This finding on $\delta^{15} \mathrm{~N}$ may be a consequence of the fact that the penguin species, despite their interspecific variations, share a similar trophic position. The intraspecific variations in TEs levels are influenced by sex (feeding and egg laying) and maturity stage of penguins (feeding habits and bioaccumulation).

\subsection{Correlations between blood and feather values}

No significant correlation was found in the present study between blood and feather TE concentrations or isotope values, except for a negative correlation for $\mathrm{Rb}$, and a positive correlation for Cu. Fenstad et al. (2017) found significant positive correlations between blood and feather concentrations for Se and $\mathrm{Cr}$; however, for the remaining elements $(\mathrm{Hg}, \mathrm{Pb}, \mathrm{Cd}, \mathrm{As}, \mathrm{Zn}$, and $\mathrm{Cu})$, blood and feather concentrations did not correlate. Taking into account stable isotopes in Pygoscelis penguins, Polito et al. (2016) observed
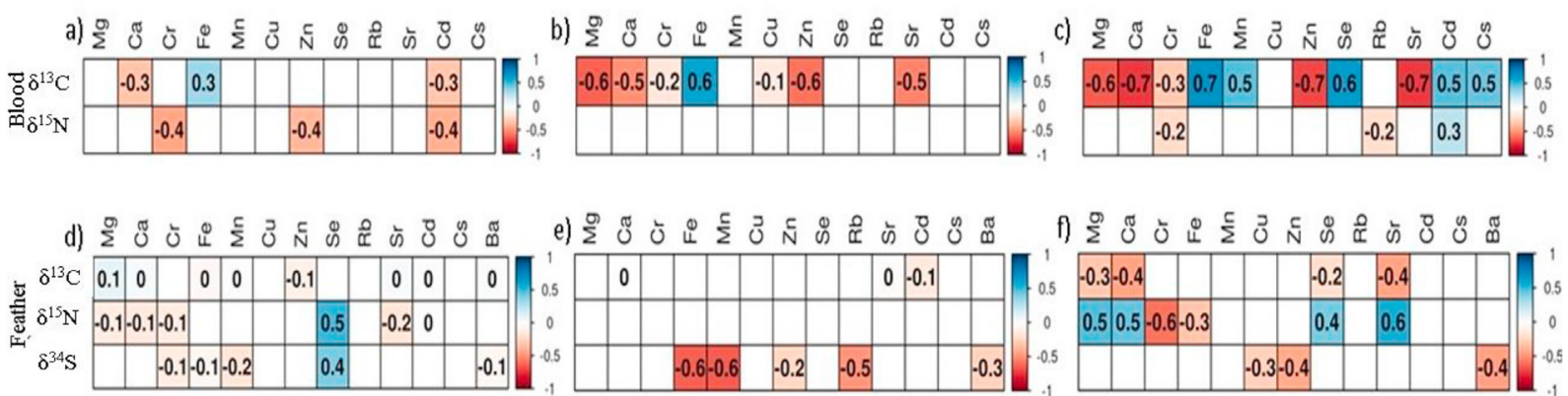

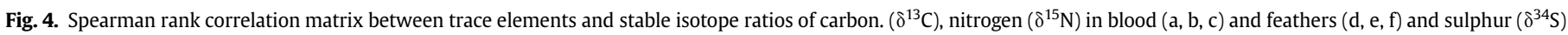

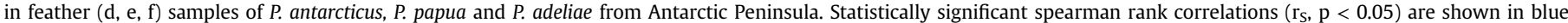

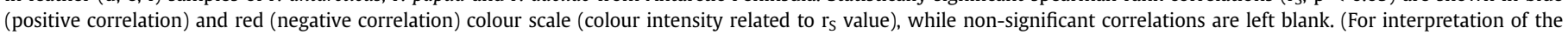
references to colour in this figure legend, the reader is referred to the Web version of this article.) 


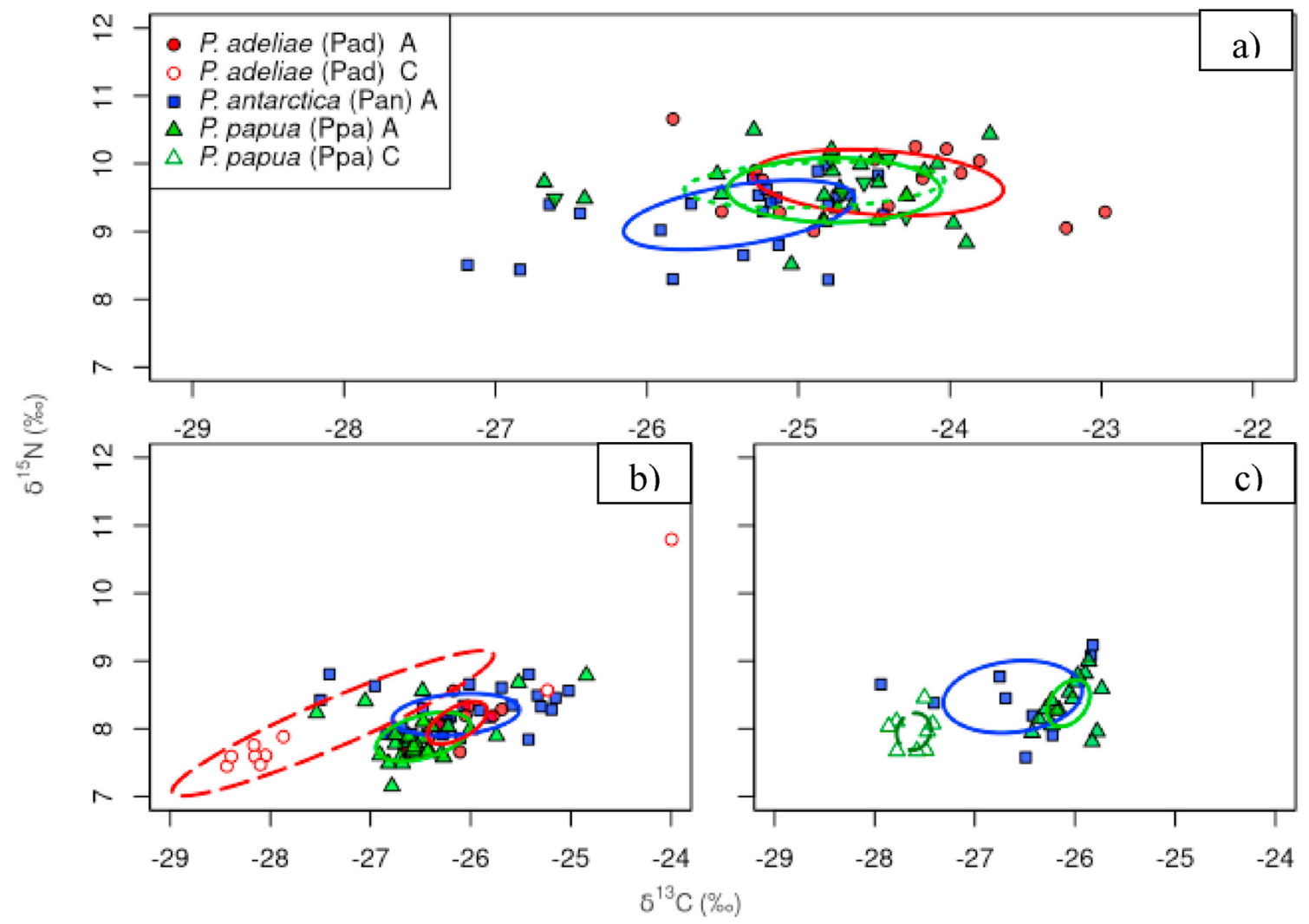

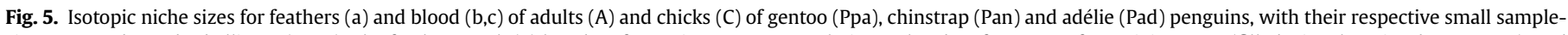

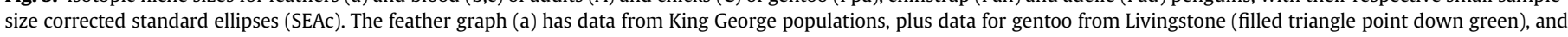

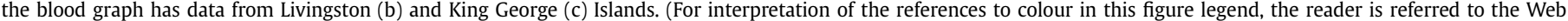
version of this article.)

significant positive correlations between blood and feather stable isotope values for $\delta^{15} \mathrm{~N}$, but not for $\delta^{13} \mathrm{C}$. The literature has not shown a clear pattern for the correlation between feather and blood TE concentrations and stable isotopes values. The trace element concentrations in blood represent a short-term dietary exposure to and/or remobilization of circulating contaminants (Evers, 2008), while feathers constitute a metabolically inert matrix, whose values correspond to a longer time period than blood (Burger, 1993). Additionally, feathers are generally enriched at ${ }^{13} \mathrm{C}$ and ${ }^{15} \mathrm{~N}$ in relation to blood, and the comparison of the raw isotopic data of these two matrices is blurred by specific factors related to the isotopic discrimination of each tissue (Kelly, 2000; Vanderklift and Ponsard, 2003). This difference in time between both matrices, added to seasonal variation in environmental parameters in Antarctica, and the variations in the ecology of the penguins can influence TE concentrations (Burger, 1993; Polito et al., 2016) and help explaining the absence of a clear pattern for correlations between feather and blood values.

\subsection{Comparison to the TE concentrations found in literature}

Essential element concentrations ( $\mathrm{Mg}, \mathrm{Ca}, \mathrm{Fe}, \mathrm{Mn}, \mathrm{Cu}, \mathrm{Zn}, \mathrm{Se}$ ) were within the range earlier reported for Southern Ocean Pygoscelis penguins, suggesting that these essential elements levels represent either background or normal physiological and ecological levels (Celis et al., 2014; Espejo et al., 2017; Jerez et al., 2011, 2013a, 2013b; Metcheva et al., 2006). Such consistency is expected, since essential elements are under homeostatic control, with the nutritional requirements of the individual regulating their absorption (Walsh, 1990). Few studies report the toxic levels of TEs in feathers; however, the literature has shown that levels starting at $200 \mu \mathrm{g}$. $\mathrm{g}^{-1}(\mathrm{dw})$ for $\mathrm{Zn}$ and at $26 \mu \mathrm{g}$. $\mathrm{g}^{-1}(\mathrm{dw})$ for Se may be harmful for birds growth and reproduction (Einoder et al., 2018). Levels reported in the present study are below these limits.

However, it is worth noting the increase in essential elements over the years, which may reflect the increase in human activities in the region. Our results suggest a certain increase in Mn levels in Antarctica compared to previous work on Pygoscelis penguins by Jerez et al. (2011; Mn $1.17 \pm 1.05 \mu \mathrm{g}$. $\mathrm{g}^{-1}$, mean $\pm \mathrm{SD}$, dw) and Metcheva et al. (2006; Mn $1.5 \pm 0.73 \mu \mathrm{g}$. $\mathrm{g}^{-1}$, mean \pm SD, dw) in feathers of $P$. papua from Livingston Island. Additionally, Mn levels found in this study were similar to those found in birds from the Northern Hemisphere (1.63-2.33 $\mu \mathrm{g}$. $\mathrm{g}^{-1}$, dw; Burger and Gochfeld, 2000), which may be an indicative of anthropogenic influence on Mn concentrations in Antarctica.

Concentrations of the non-essential elements $\mathrm{Li}, \mathrm{Be}, \mathrm{Cr}, \mathrm{Rb}, \mathrm{Sr}$, $\mathrm{Sn}, \mathrm{Ba}$, and $\mathrm{Pb}$ were in a similar range to those found in Pygoscelis spp and other penguins worldwide (Espejo et al., 2017; Finger, 2017; Jerez et al., 2011, 2013b; Metcheva et al., 2006). The present study showed higher $\mathrm{Cd}$ concentrations than those determined by previous studies in the same species (Espejo et al., 2017; Jerez et al., 2011; Metcheva et al., 2006), and higher than values reported for feathers of the Procellariiforme Antarctic prion (Pachyptila desolata) (Fromant et al., 2016). This could indicate an anthropogenic influence in environmental concentrations of this metal in King George Island, since this region has the highest number of multinational 
A)

\section{Model estimations of SEA}

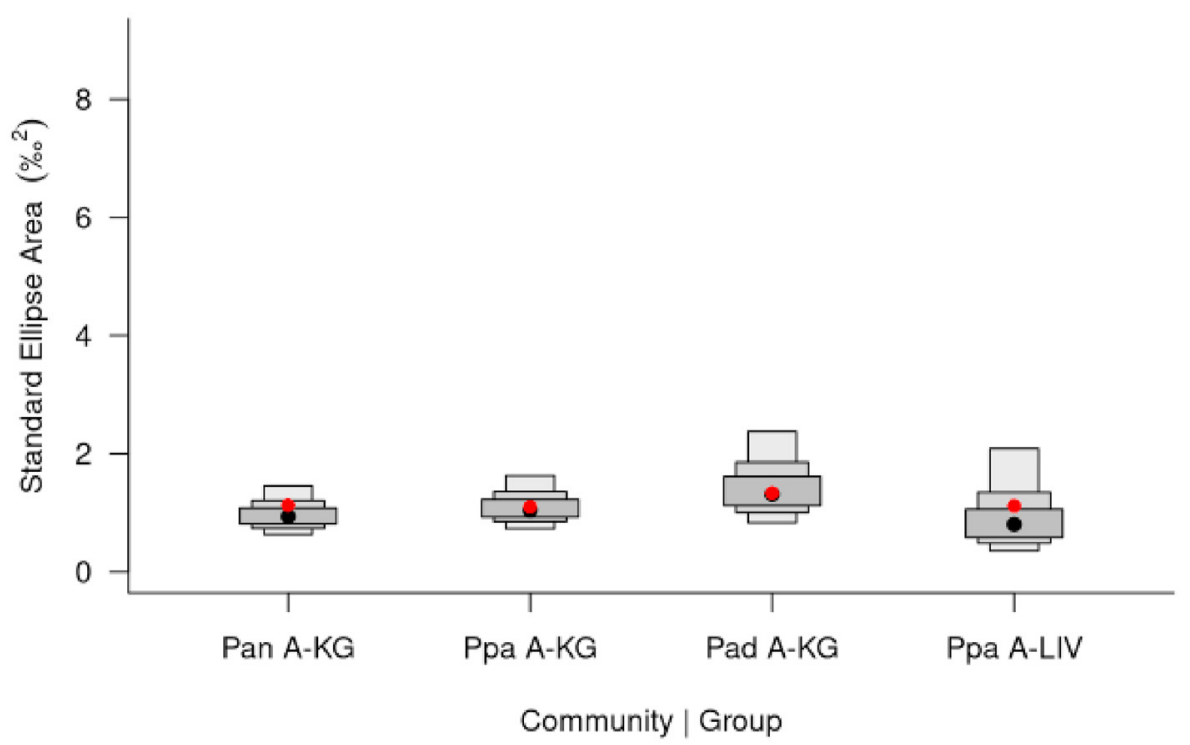

B)

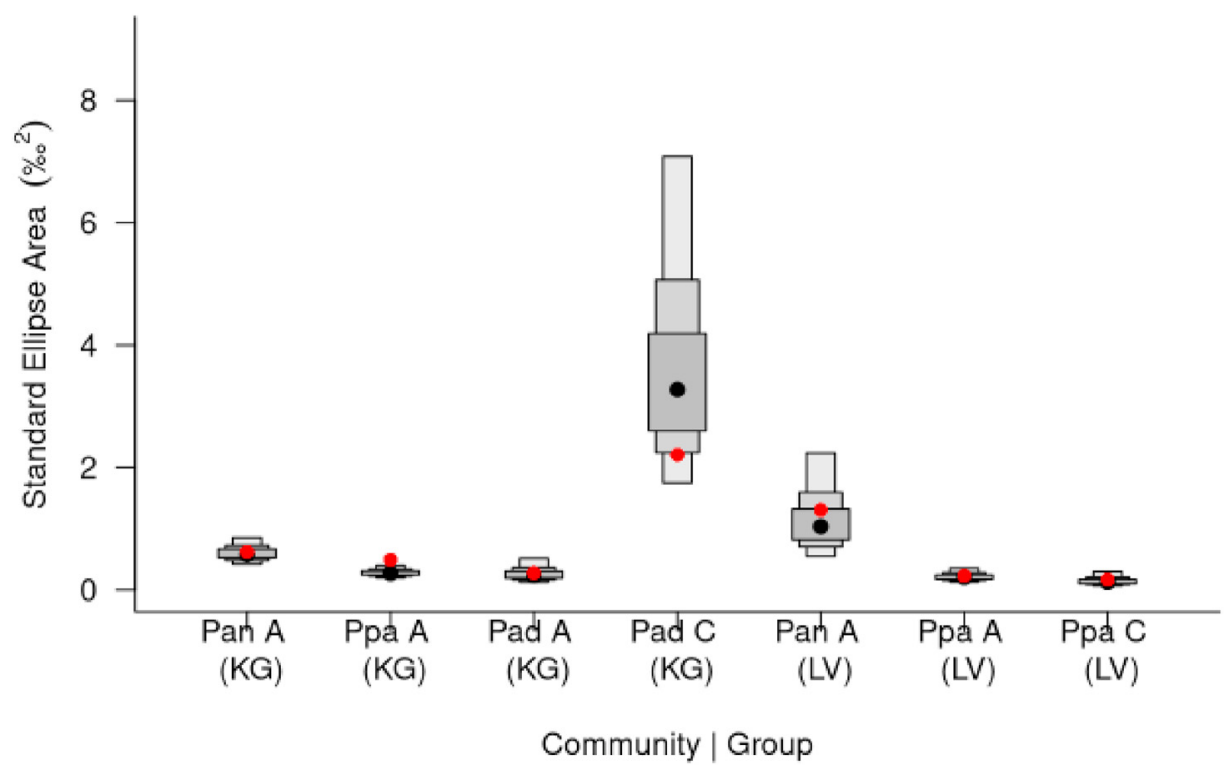

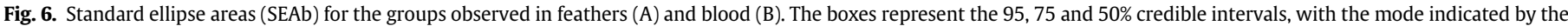

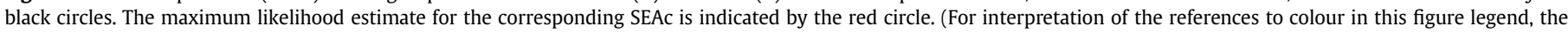
reader is referred to the Web version of this article.)

facilities in Antarctica (nine permanent stations and a runway), being also one of the favorite destinations for tourist cruises in the continent.

Chromium and $\mathrm{Pb}$ were lower than those observed by Jerez et al. (2011) in feathers of Pygoscelis penguins: 1.15-8.08 for $\mathrm{Cr}$ and $0.14-1.76$ for $\mathrm{Pb} \mu \mathrm{g}$. $\mathrm{g}^{-1}$ dry weight (dw). However, $\mathrm{Pb}$ values were similar to those observed by Finger et al. (2017) in blood of little penguin (Eudyptula minor) $\left(0.04-0.07 \mu \mathrm{g} . \mathrm{g}^{-1} \mathrm{dw}\right.$ ) from Australian Coast, a more polluted area. Chromium and $\mathrm{Pb}$ concentrations are associated to major human presence and activities in the Antarctic Peninsula (Jerez et al., 2011). Temporal studies on Antarctic snow have shown that elements such as $\mathrm{Cr}$ and $\mathrm{Pb}$ have increased their levels over the years (Hur et al., 2007; Planchon et al., 2002). This fact is probably due to the transport of elements from anthropic activities, such as mining and smelting of non-ferrous metals, carried out in southern hemisphere countries (Hur et al., 2007; Planchon et al., 2002). 


\subsection{Geographical differences}

Volcanic activities increase the concentrations of several TEs in marine and continental ecosystems and Livingston is near to Deception Island, an active submarine volcano (Almendros, 1997). The local geothermal activity generates higher concentrations of $\mathrm{Mn}, \mathrm{Zn}$, and Fe in environmental matrices and biota (Deheyn et al., 2005). This fact may explain the higher concentrations of these three metals in P. papua from Livingston compared to King George Island. However, it is worth mentioning that there was an absence of geographically-related differences for the remaining measured elements, despite the distinct geothermal and prey availability in the different locations. This may be related to the proximity of the two islands, where the collection points are less than $100 \mathrm{~km}$ apart. Celis et al. (2014) collected soil samples from different locations in Antarctica, and observed great variations among the studied locations, most of them decreasing along the latitudinal gradient, related to the decrease of human presence and activities from North to South. Additionally, penguins often cover huge distances when feeding, making foraging trips that exceed $100 \mathrm{~km}$ (Davis and Darby, 2012), despite breeding in different locations, they feed in much wider areas, which can also contribute to the dilution of the effect of chemical inputs.

Another factor that can also influence the geographical differences in trace element levels is the availability of prey in different locations, corroborated by our $\mathrm{SEA}_{\mathrm{b}}$ data, in which variations in the trophic niche of Pygoscelis penguins were observed between King George and Livingston. The availability of prey is a determining factor in the feeding plasticity of the penguins, and such availability can change not only in different locations, but also over the years (Miller et al., 2010).

\subsection{Interspecific differences}

Interspecific patterns of $\delta^{13} \mathrm{C}, \delta^{15} \mathrm{~N}$ and $\delta^{34} \mathrm{~S}$ indicate that the three species have differences in foraging habits. The ratio of stable nitrogen isotopes is typically used as a tracer of the trophic level occupied by the species, and carbon and sulphur stable isotope ratios are commonly used to identify the sources of organic matter that sustain food webs (Connolly et al., 2004; Pizzochero, 2017; Polito et al., 2016). Most correlations between trace element concentrations and stable isotope values were negative and observed for $\delta^{15} \mathrm{~N}, \delta^{13} \mathrm{C}$ and $\delta^{34} \mathrm{~S}$. TE levels are, in general, found in close relationship with the foraging habitat, in a way that lower TE levels are usually found in habitats with very negative $\delta^{13} \mathrm{C}$ and low $\delta^{34} \mathrm{~S}$ (i.e., more pelagic/open areas), and higher concentrations are verified in coastal habitats. The correlations between TE and $\delta^{34} \mathrm{~S}$ suggest an important contribution from coastal or benthic food webs. The latter statement is based on the fact that producers from open marine and pelagic environments typically have higher $\delta^{34} \mathrm{~S}$ values compared to coastal benthic sediment-associated producers (Connolly et al., 2004).

Our $\mathrm{SEA}_{\mathrm{b}}$ results suggest that the niches of the three adult species have a similar size, however suggests a greater differentiation of $P$. antarcticus in relation to other species. Our results show that the diet plays an important role in the exposure of Pygoscelis penguins to TEs. Although krill is the main dietary component of Pygoscelis penguins in the Antarctic peninsula region, variations in the proportion of fish consumed (Polito et al., 2016; Volkman, 1980), as well as the foraging area (Herman et al., 2017) might explain our findings. Previous studies at King George Island have indicated a greater use of offshore foraging habitats by $P$. adeliae and $P$. antarcticus relative to $P$. papua (Miller et al., 2010; Polito et al., 2016), and our data corroborate those findings. Herman et al. (2017) observed that $P$. antarcticus have a specialized diet, which feeds more on krill, compared to generalist strategy presented by $P$. papua and the intermediary one presented by $P$. adeliae. These findings may help explaining the significantly lower values of $\delta^{15} \mathrm{~N}$, and higher concentrations of $\mathrm{Cu}, \mathrm{Cd}$ and Se found for $P$. antarcticus in the present study.

The Antarctic krill contains high amounts of $\mathrm{Cu}$ as a component of hemocyanin, their blood pigment (Nygård et al., 2001). This would explain the greatest $\mathrm{Cu}$ concentrations in $P$. antarcticus, which also exhibited the lowest $\delta^{15} \mathrm{~N}$ values. These stable isotope values are coherent with the lower trophic position occupied by krill in comparison to the fish consumed by the penguins (Polito et al., 2016). Cadmium is another element also found in high concentrations in krill. Nygård et al. (2001) associated the deep ocean upwelling to the high Cd concentrations in Antarctic krill, which may explain high Cd levels in P. antarcticus.

\subsection{Intraspecific differences}

Regarding the investigation of possible sex-related variations, the results on $\delta^{13} \mathrm{C}$ and $\delta^{15} \mathrm{~N}$ values in $P$. papua indicate differences in diet and/or foraging areas between males and females. Xavier et al. (2017) observed that males of $P$. papua feed at a higher trophic level than females. The present study showed the same pattern in blood samples, since males were ${ }^{15} \mathrm{~N}$-enriched compared to females. Previous studies have shown that males rely more on fish than females and this feeding pattern is observed in both adults and chicks (Jennings et al., 2016; Miller et al., 2010; Xavier et al., 2017). Differences in diet between males and females have been also reported for $P$. adeliae (Jennings et al., 2016), as male chicks were fed a greater proportion of fish than female chicks due to differences in the pattern of parental feeding. The literature shows sex-related differences in diet and foraging habitat for $P$. papua (Bearhop et al., 2006), but no gender-related differences were observed for P. adeliae or P. antarcticus (Miller et al., 2010). Polito et al. (2015) found little to no dietary differences between sexes for P. antarcticus and P. papua. Likewise, Gorman et al. (2014) found sex-related differences in $\delta^{15} \mathrm{~N}$ values for $P$. antarcticus and $P$. papua in the same magnitude as analytical measurement error and no sex-related differences in $\delta^{13} \mathrm{C}$ values.

Regarding ontogenetic differences, our $\mathrm{SEA}_{\mathrm{b}}$ data showed the isotopic niches of chicks were markedly separated from that of adults, which suggests both age classes have different ecological niches, reflecting also in their trace element concentrations. The scientific literature on stable isotope data shows that diet composition can differ between adults and chicks (Tierney, 2008). The fact that adults preferentially fed the chicks with fish rather than with invertebrates (Jerez et al., 2013a; Tierney, 2008) may help explaining the results. In addition, the higher concentrations of Se, $\mathrm{Cd}$, and $\mathrm{Fe}$ found in adults compared to chicks seems to be a consequence of the bioaccumulation process, which is the increase in pollutants throughout life (Wang, 2016), since the literature has been observed an increase of Cd (Burger and Gochfeld, 2000), and Se (Padilha et al., 2018) with age in seabirds.

Ontogenetic and gender-related differences were found for $\mathrm{Ca}$ concentrations. In blood samples, negative correlations were found between Ca levels and stable isotope data $\left(\delta^{13} \mathrm{C}\right.$ and $\left.\delta^{15} \mathrm{~N}\right)$. Still regarding this alkaline-earth metal, our results were similar to the concentrations found by Janssens (2001; 904-1160 $\mu \mathrm{g} . \mathrm{g}^{-1} \mathrm{dw}$ ) while analyzing feathers of birds from Belgium. Newman et al. (1997) observed that plasma calcium concentrations differed between male and female seabirds from Alaska. These differences occur due to egg laying, which alters Ca concentrations in females (Newman, 1997).

Rubidium varied between locality, species, gender, and negative correlations were observed between this alkali metal and stable 
isotope values $\left(\delta^{13} \mathrm{C}\right.$ and $\left.\delta^{34} \mathrm{~S}\right)$, indicating that many factors are influencing the distribution of this element within Pygoscelis spp. Campbell (2005) observed biomagnification of Rb in Arctic and temperate aquatic food webs. We observed significantly positive correlation between Rb concentrations and $\delta^{15} \mathrm{~N}$ values in P. adeliae feathers which can support the tendency of Rb to biomagnify.

\section{Conclusions}

Our results reinforce the value of environmental studies engaged in sampling efforts using different species, age class, and gender at different geographic areas. The use of a single species of the same age and sex, in the same location limits the comprehension of all the factors that may influence the exposure of that population to a particular contaminant. Our approach demonstrated the combined influence of several factors on the exposure to TEs and therefore, better reflects general trends. We confirm that geographical location, foraging zone $\left(\delta^{13} \mathrm{C}\right.$ and $\left.\delta^{34} \mathrm{~S}\right)$ and diet influence the interspecific differences among Pygoscelis penguins. In addition, intraspecific variations in TE levels are influenced by sex (feeding and egg laying) and maturity stage of penguins (feeding habits).

Our results also showed that some of the TEs concentrations were similar to those measured in birds from the Northern Hemisphere $(\mathrm{Mn}, \mathrm{Cr}, \mathrm{Pb}, \mathrm{Cd})$, where there is greater anthropogenic pressure. The apparent increase in $\mathrm{Mn}$ and $\mathrm{Cd}$ concentrations compared to previous studies reinforces the importance of monitoring polar birds in future investigations, since the increase in human activities at a local and global scale may lead to the exposure of these animals to pollutants.

This study presents essential baseline data that will assist in future investigations seeking to use Pygoscelis penguins as sentinels for TEs availability in the Antarctic marine environments. For TEs trophodynamics studies, it is recommended to incorporate species that compose penguin diet in the sampling design. Further investigations should also aim to understand in depth the role of sex and age in TEs trophodynamics in Pygoscelis penguins. Furthermore, additional studies should aim to provide further clarification of the factors that influence TEs concentrations in different penguin populations.

\section{Limitations}

Antarctica is a remote location difficult to access; therefore, sampling in some cases is limited and incomplete. In the present study, logistical limitations for moving to different collection sites made it impossible to collect an adequate number of chick samples as well as blood for the molecular determination of sex in the species of the two sampled locations. Although not ideal, as those were rare, difficult to access and therefore valuable samples, the study was carried out with a reduced sample size in some cases. However, this fact does not reduce the scientific relevance of the results obtained or change how this study can help future investigations to understand the factors that influence the exposure of Pygoscelis penguins to TEs.

\section{Credit author statement}

Janeide de Assis Padilha: Conceptualization, Visualization, Formal analysis, Investigation, Methodology and Writing - review \& editing, Gabriel Oliveira de Carvalho: Visualization, Formal analysis, and Writing - review \& editing, Dr. Winfred Espejo: Visualization, Formal analysis, and Writing - review \& editing, Juliana Silva Souza: Investigation, Methodology and Writing - review \& editing: Dr. Ana Carolina Pizzochero: Conceptualization, Formal analysis, Methodology, Writing - review \& editing: Dr. Larissa S. T Cunha: Conceptualization, Methodology, Writing - review \& editing, Dr. Erli S. Costa: Conceptualization, Methodology, Writing review \& editing, MSc. Adriana Rodrigues de Lira Pessoa, Investigation, Methodology and Writing - review \& editing, André Pinheiro de Almeida: Methodology and Writing - review \& editing, João Paulo Machado Torres: Conceptualization, Funding acquisition, Investigation and Writing - review \& editing: Gilles Lepoint: Funding acquisition, Investigation, Writing - review \& editing and Supervision, Loïc N. Michel: Investigation and Writing - review \& editing, Krishna Das: Conceptualization, Supervision, Funding acquisition, Investigation and Writing - review \& editing: Paulo Renato Dorneles: Conceptualization, Supervision, Funding acquisition, Investigation and Writing - review \& editing.

\section{Declaration of competing interest}

The authors declare that they have no known competing financial interests or personal relationships that could have appeared to influence the work reported in this paper.

\section{Acknowledgements}

This work was supported by the Brazilian National Council for Scientific and Technological Development (CNPq) through CNPq / MCT 557049/2009-1, as well as through a Universal Call CNPq Project from PRD (proc. 432518/2016-9). This work was also supported by a scientific cooperation established between the Brazilian Foundation for the Coordination and Improvement of Higher Level or Education Personnel (CAPES - process numbers 88881.154725/ 2017-01 88887.154724/2017-00) and Wallonie Bruxelles International (WBI, from Belgium), coordinated by PRD and KD, as well as by the Rio de Janeiro State Government Research Agency [FAPERJ E-26/111.505/2010 and E - 26/210.464/2019 (249593)]. We would like to thank the Brazilian Navy, which provided logistical support in Antarctica through the "Secretariat of the Interministerial Commission for the Resources of the Sea" (SECIRM). GL is a F.R.S.-FNRS research associate, and KD is a Senior F.R.S.- FNRS research associate. PRD has a research grant from CNPq (PQ-2 proc. 08733/ 2019-3).

\section{Appendix A. Supplementary data}

Supplementary data to this article can be found online at https://doi.org/10.1016/j.envpol.2021.117209.

\section{References}

Abrams, R.W., 1985. Energy and food requirements of pelagic aerial seabirds in different regions of the african sector of the Southern Ocean. In: Siegfried, W.R. Condy, P.R., Laws, R.M. (Eds.), Antarctic Nutrient Cycles and Food Webs. Springer, Berlin, Heidelberg, pp. 466-472. https://doi.org/10.1007/978-3-64282275-9 65.

Almendros, J., et al., 1997. Array tracking of the volcanic tremor source at Deception Island, Antarctica. Geophys. Res. Lett. 24, 3069-3072.

Bargagli, R., 2008. Environmental contamination in Antarctic ecosystems. Sci. Total Environ. 400, 212-226. https://doi.org/10.1016/j.scitotenv.2008.06.062.

Bargagli, R., Nelli, L., Ancora, S., Focardi, S., 1996. Elevated cadmium accumulation in marine organisms from Terra Nova Bay (Antarctica). Polar Biol. 16, 513-520. https://doi.org/10.1007/BF02329071.

Bearhop, S., Phillips, R.A., McGill, R., Cherel, Y., Dawson, D.A., Croxall, J.P., 2006. Stable isotopes indicate sex-specific and long-term individual foraging specialisation in diving seabirds. Mar. Ecol. Prog. Ser. 311, 157-164. https:// doi.org/10.3354/meps311157.

Bengtson Nash, S., Rintoul, S., Staniland, I., Van den Hoff, J., Tierney, M., Bossi, R., 2010. Perfluorinated compounds in the Antarctic region: ocean circulation provides prolonged protection from distant sources. Environ. Pollut. Barking Essex 1987 (158), 2985-2991. https://doi.org/10.1016/j.envpol.2010.05.024.

Burger, J., 1993. Metals in avian feathers: bioindicators of environmental pollution. Rev Env. Toxicol 5, 203-311. 
Burger, J., Gochfeld, M., 2000. Metal levels in feathers of 12 species of seabirds from Midway Atoll in the northern Pacific Ocean. Sci. Total Environ. 257, 37-52. https://doi.org/10.1016/S0048-9697(00)00496-4.

Campbell, Linda M., et al., 2005. Mercury and other trace elements in a pelagic Arctic marine food web (Northwater Polynya, Baffin Bay). Sci. Total Environ. 351-352, 247-263. https://doi.org/10.1016/j.scitotenv.2005.02.043.

Carravieri, A., Cherel, Y., Blévin, P., Brault-Favrou, M., Chastel, O., Bustamante, P., 2014. Mercury exposure in a large subantarctic avian community. Environ. Pollut. 190, 51-57. https://doi.org/10.1016/j.envpol.2014.03.017.

Celis, José, et al., 2012. A preliminary study of trace metals and porphyrins in excreta of Gentoo penguins (Pygoscelis papua) at two locations of the Antarctic Peninsula. Archivos de medicina veterinaria 44, 311-316. https://doi.org/ 10.4067/S0301-732X2012000300016.

Celis, José, et al., 2015. Trace element concentrations in biotic matrices of gentoo penguins (Pygoscelis papua) and coastal soils from different locations of the Antarctic Peninsula. Water, Air, Soil Pollut. 226, 1-12. https://doi.org/10.1007/ s11270-014-2266-5.

Celis, J.E., Barra, R., Espejo, W., González-Acuña, D., Jara, S., 2014. Trace element concentrations in biotic matrices of gentoo penguins (Pygoscelis papua) and coastal soils from different locations of the antarctic peninsula. Water, Air, Soil Pollut. 226, 2266. https://doi.org/10.1007/s11270-014-2266-5.

Colominas-Ciuró, R., Santos, M., Coria, N., Barbosa, A., 2018. Sex-specific foraging strategies of Adélie penguins (Pygoscelis adeliae): females forage further and on more krill than males in the Antarctic Peninsula. Polar Biol. 41, 2635-2641. https://doi.org/10.1007/s00300-018-2395-1.

Connolly, R.M., Guest, M.A., Melville, A.J., Oakes, J.M., 2004. Sulfur stable isotopes separate producers in marine food-web analysis. Oecologia 138, 161-167.

Das, K., Malarvannan, G., Dirtu, A., Dulau, V., Dumont, M., Lepoint, G., Mongin, P., Covaci, A., 2017. Linking pollutant exposure of humpback whales breeding in the Indian Ocean to their feeding habits and feeding areas off Antarctica. Environ. Pollut. 220, 1090-1099. https://doi.org/10.1016/j.envpol.2016.11.032.

Data \& Statistics - Iaato [WWW Document], n.d. URL https://iaato.org/informationresources/data-statistics/(accessed 3.2.21).

Davis, L.S., Darby, J.T., 2012. Penguin Biology. Elsevier.

Deheyn, D.D., Gendreau, P., Baldwin, R.J., Latz, M.I., 2005. Evidence for enhanced bioavailability of trace elements in the marine ecosystem of Deception Island, a volcano in Antarctica. Mar. Environ. Res. 60, 1-33. https://doi.org/10.1016/ j.marenvres.2004.08.001.

Dobaradaran, S., Soleimani, F., Nabipour, I., Saeedi, R., Mohammadi, M.J., 2018. Heavy metal levels of ballast waters in commercial ships entering Bushehr port along the Persian Gulf. Mar. Pollut. Bull. 126, 74-76. https://doi.org/10.1016/ j.marpolbul.2017.10.094.

Einoder, L.D., MacLeod, C.K., Coughanowr, C., 2018. Metal and isotope analysis of bird feathers in a contaminated estuary reveals bioaccumulation, biomagnification, and potential toxic effects. Arch. Environ. Contam. Toxicol. 75, 96-110. https://doi.org/10.1007/s00244-018-0532-z.

Espejo, W., Celis, J.E., GonzÃlez-Acuña, D., Banegas, A., Barra, R., Chiang, G., 2017. A global overview of exposure levels and biological effects of trace elements in penguins. In: Reviews of Environmental Contamination and Toxicology Volume 245, Reviews of Environmental Contamination and Toxicology. Springer, Cham, pp. 1-64. https://doi.org/10.1007/398_2017_5.

Evers, David C., et al., 2008. Adverse effects from environmental mercury loads on breeding common loons. Ecotoxicology 17, 69-81. https://doi.org/10.1007/ s10646-007-0168-7.

Fenstad, A.A., Bustnes, J.O., Lierhagen, S., Gabrielsen, K.M., Öst, M., Jaatinen, K., Hanssen, S.A., Moe, B., Jenssen, B.M., Krøkje, Å., 2017. Blood and feather concentrations of toxic elements in a Baltic and an Arctic seabird population. Mar. Pollut. Bull. 114, 1152-1158. https://doi.org/10.1016/j.marpolbul.2016.10.034.

Finger, Annett, et al., 2017. Metals and metalloids in Little Penguin (Eudyptula minor) prey, blood and faeces. Environ. Pollut. 223, 567-574. https://doi.org/ 10.1016/j.envpol.2017.01.059.

Fromant, A., Carravieri, A., Bustamante, P., Labadie, P., Budzinski, H., Peluhet, L., Churlaud, C., Chastel, O., Cherel, Y., 2016. Wide range of metallic and organic contaminants in various tissues of the Antarctic prion, a planktonophagous seabird from the Southern Ocean. Sci. Total Environ. 544, 754-764. https:// doi.org/10.1016/j.scitotenv.2015.11.114.

Gorman, K.B., Williams, T.D., Fraser, W.R., 2014. Ecological sexual dimorphism and environmental variability within a community of antarctic penguins (genus Pygoscelis). PloS One 9, e90081. https://doi.org/10.1371/journal.pone.0090081.

Griffiths, R., Double, M.C., Orr, K., Dawson, R.J.G., 1998. A DNA test to sex most birds. Mol. Ecol. 7, 1071-1075. https://doi.org/10.1046/j.1365-294x.1998.00389.x.

Herman, R.W., Valls, F.C.L., Hart, T., Petry, M.V., Trivelpiece, W.Z., Polito, M.J., 2017. Seasonal consistency and individual variation in foraging strategies differ among and within Pygoscelis penguin species in the Antarctic Peninsula region. Mar. Biol. 164, 115. https://doi.org/10.1007/s00227-017-3142-9.

Hong, S.-M., Lluberas, A., Lee, G.-W., Park, J.-K., 2002. Natural and anthropogenic heavy metal deposition to the snow in king George island, antarctic peninsula. Ocean Polar Res. 24, 279-287. https://doi.org/10.4217/OPR.2002.24.3.279.

Hur, S.D., Cunde, X., Hong, S., Barbante, C., Gabrielli, P., Lee, K., Boutron, C.F., Ming, Y., 2007. Seasonal patterns of heavy metal deposition to the snow on Lambert Glacier basin, East Antarctica. Atmos. Environ. 41, 8567-8578. https://doi.org/ 10.1016/j.atmosenv.2007.07.012.

Jackson, A.L., et al., 2011. Comparing isotopic niche widths among and within communities: SIBER-Stable Isotope Bayesian Ellipses in R. J. Anim. Ecol. 80, 595-602. https://doi.org/10.1111/j.1365-2656.2011.01806.x.
Janssens, Ellen, et al., 2001. Heavy metals and selenium in feathers of great tits (Parus major) along a pollution gradient. Environ. Toxicol. Chem.: Int. J. 2815-2820. https://doi.org/10.1002/etc.5620201221.

Jennings, S., Varsani, A., Dugger, K.M., Ballard, G., Ainley, D.G., 2016. Sex-based differences in adélie penguin (Pygoscelis adeliae) chick growth rates and diet. PloS One 11, e0149090. https://doi.org/10.1371/journal.pone.0149090.

Jerez, S., Motas, M., Benzal, J., Diaz, J., Barbosa, A., 2013a. Monitoring trace elements in antarctic penguin chicks from South Shetland islands, Antarctica. Mar. Pollut. Bull. 69, 67-75. https://doi.org/10.1016/j.marpolbul.2013.01.004.

Jerez, S., Motas, M., Benzal, J., Diaz, J., Vidal, V., D’Amico, V., Barbosa, A., 2013b. Distribution of metals and trace elements in adult and juvenile penguins from the Antarctic Peninsula area. Environ. Sci. Pollut. Res. 20, 3300-3311. https:// doi.org/10.1007/s11356-012-1235-z.

Jerez, S., Motas, M., Palacios, M.J., Valera, F., Cuervo, J.J., Barbosa, A., 2011. Concentration of trace elements in feathers of three Antarctic penguins: geographical and interspecific differences. Environ. Pollut., Nitrogen Deposition, Critical Loads and Biodiversity 159, 2412-2419. https://doi.org/10.1016/ j.envpol.2011.06.036.

Jiankan, H., Zichu, X., Fengnian, D., Wanchang, Z., 1999. Volcanic eruptions recorded in an ice core from collins ice cap, king George island, Antarctica. Ann. Glaciol. 29, 121-125. https://doi.org/10.3189/172756499781821139.

Kakareka, S., Kukharchyk, T., Kurman, P., 2020. Study of trace elements in the surface snow for impact monitoring in Vecherny Oasis, East Antarctica. Environ. Monit. Assess. 192, 725. https://doi.org/10.1007/s10661-020-08682-8.

Kelly, Jeffrey F., 2000. Stable isotopes of carbon and nitrogen in the study of avian and mammalian trophic ecology. Can. J. Zool. 78, 1-27. https://doi.org/10.1139/ z99-165.

Marques, R. C, et al., 2007. Maternal mercury exposure and neuro-motor development in breastfed infants from Porto Velho (Amazon), Brazil. Int. J. Hyg Environ. Health 210, 51-60. https://doi.org/10.1016/j.ijheh.2006.08.001.

Metcheva, R., Yurukova, L., Bezrukov, V., Beltcheva, M., Yankov, Y., Dimitrov, K., 2010. Trace and toxic elements accumulation in food chain representatives at Livingston Island (Antarctica). Int. J. Biol. 2, 155.

Metcheva, R., Yurukova, L., Teodorova, S., Nikolova, E., 2006. The penguin feathers as bioindicator of Antarctica environmental state. Sci. Total Environ. 362, 259-265. https://doi.org/10.1016/j.scitotenv.2005.05.008.

Miller, A.K., Kappes, M.A., Trivelpiece, S.G., Trivelpiece, W.Z., 2010. Foraging-Niche Separation of Breeding Gentoo and Chinstrap Penguins, South Shetland Islands, AntarcticaSeparación de Nicho de Forrajeo durante el Periodo de Cría en los Pingüinos Pygoscelis papua y P. Antarctica, en las Islas Shetland del Sur, Antártica. Condor 112, 683-695. https://doi.org/10.1525/cond.2010.090221.

Nash, S.B, 2011. Persistent organic pollutants in Antarctica: current and future research priorities. J. Environ. Monit 497-504. https://doi.org/10.1039/ COEM00230E.

Newman, S.H., et al., 1997. Hematological and plasma biochemical reference ranges of Alaskan seabirds: their ecological significance and clinical importance. Colon. Waterbirds 20, 492-504. https://doi.org/10.2307/1521600.

Nordberg, G.F., Fowler, B.A., Nordberg, M., 2014. Handbook on the Toxicology of Metals. Academic Press.

Nygård, T., Lie, E., Røv, N., Steinnes, E., 2001. Metal dynamics in an antarctic food chain. Mar. Pollut. Bull. 42, 598-602. https://doi.org/10.1016/S0025-326X(00) 00206-X.

Padilha, J.D.A., Da Cunha, L.S.T., De Castro, R.M., Malm, O., Dorneles, P.R., 2018. Exposure of magnificent frigatebird (Fregata magnificens) and Brown booby (Sula leucogaster) to metals and selenium in Rio de Janeiro state (Brazil) coastal waters. Orbital - Electron. J. Chem. 10, 254-261. https://doi.org/10.17807/ orbital.v10i2.1050.

Pizzochero, A.C., et al., 2017. Use of multielement stable isotope ratios to investigate ontogenetic movements of Micropogonias furnieri in a tropical Brazilian estuary. Can. J. Fish. Aquat. Sci. 75, 977-986. https://doi.org/10.1139/cjfas-2017-0148.

Planchon, F.A.M., Boutron, C.F., Barbante, C., Cozzi, G., Gaspari, V., Wolff, E.W., Ferrari, C.P., Cescon, P., 2002. Changes in heavy metals in Antarctic snow from Coats Land since the mid-19th to the late-20th century. Earth Planet Sci. Lett. 200, 207-222. https://doi.org/10.1016/S0012-821X(02)00612-X.

Polito, M.J., Brasso, R.L., Trivelpiece, W.Z., Karnovsky, N., Patterson, W.P., Emslie, S.D., 2016. Differing foraging strategies influence mercury $(\mathrm{Hg})$ exposure in an Antarctic penguin community. Environ. Pollut. 218, 196-206. https://doi.org/ 10.1016/j.envpol.2016.04.097.

Polito, M.J., Trivelpiece, W.Z., Patterson, W.P., Karnovsky, N.J., Reiss, C.S., Emslie, S.D. 2015. Contrasting specialist and generalist patterns facilitate foraging niche partitioning in sympatric populations of Pygoscelis penguins. Mar. Ecol. Prog. Ser. 519, 221-237. https://doi.org/10.3354/meps11095.

R Core Team, 2019. R: A Language and Environment for Statistical Computing. R Foundation for Statistical Computing.

Tierney, Megan, et al., 2008. Evaluating and using stable-isotope analysis to infer diet composition and foraging ecology of Adélie penguins Pygoscelis adeliae. Mar. Ecol.: Prog. Ser. 355, 297-307. https://doi.org/10.3354/meps07235.

Tin, T., Fleming, Z.L., Hughes, K.A., Ainley, D.G., Convey, P., Moreno, C.A., Pfeiffer, S., Scott, J., Snape, I., 2009. Impacts of local human activities on the Antarctic environment. Antarct. Sci. 21, 3-33. https://doi.org/10.1017/ S0954102009001722.

Trivelpiece, W.Z., Trivelpiece, S.G., Volkman, N.J., 1987. Ecological segregation of adelie, gentoo, and chinstrap penguins at king George island, Antarctica. Ecology 68, 351-361. https://doi.org/10.2307/1939266.

Vanderklift, Mathew A., Ponsard, Sergine, 2003. Sources of variation in consumer- 
diet d15N enrichment: a meta-analysis. Oecologia 136, 169-182. https:// doi.org/10.1007/s00442-003-1270-z.

Volkman, N.J., et al., 1980. Diets of pygoscelid penguins at King George Island, Antarctica. Condor 373-378.

Walsh, P.M., 1990. The use of seabirds as monitors of heavy metals in the marine environment. Heavy Met. Mar. Environ. 10, 183-204.

Wang, W.-X., 2016. Chapter 4 - bioaccumulation and biomonitoring. In: Blasco, J.,
Chapman, P.M., Campana, O., Hampel, M. (Eds.), Marine Ecotoxicology. Academic Press, pp. 99-119. https://doi.org/10.1016/B978-0-12-803371-5.00004-7. Xavier, J.C., Trathan, P.N., Ceia, F.R., Tarling, G.A., Adlard, S., Fox, D., Edwards, E.W.J., Vieira, R.P., Medeiros, R., Broyer, C.D., Cherel, Y., 2017. Sexual and individual foraging segregation in Gentoo penguins Pygoscelis papua from the Southern Ocean during an abnormal winter. PloS One 12, e0174850. https://doi.org/ 10.1371 /journal.pone.0174850. 